\title{
Integrated calcareous nannofossil and ammonite data from the upper Barremian-lower Albian of the northeastern Transdanubian Range (central Hungary): Stratigraphical implications and consequences for dating tectonic events
}

\author{
O. Szives ${ }^{a,}{ }^{*}$, L. Fodor ${ }^{\mathrm{b}, \mathrm{c}}$, A. Fogarasi ${ }^{\mathrm{d}}$, Sz Kövér ${ }^{\mathrm{b}}$ \\ ${ }^{a}$ Hungarian Natural History Museum, Baross $u .13,1088$ Budapest, Hungary \\ ${ }^{\mathrm{b}}$ MTA-ELTE Geological, Geophysical and Space Science Research Group, Pázmány P. 1/C, 1117 Budapest, Hungary \\ ${ }^{\mathrm{c}}$ MTA-ELTE Volcanological Research Group, Pázmány P. 1/C, 1117 Budapest, Hungary \\ ${ }^{\mathrm{d}}$ MOL Energy UK Ltd, Riverside House, Riverside Drive, Aberdeen, Scotland, United Kingdom
}

\section{A R T I C L E I N F O}

\section{Article history:}

Received 24 January 2018

Received in revised form 18 May 2018

Accepted in revised form 7 June 2018

Available online 19 June 2018

\section{Keywords:}

Nannoplankton

Ammonites

Biostratigraphy

Early Cretaceous

Eo-Alpine

Tectonics

\begin{abstract}
A B S T R A C T
The transition of post-obduction Neotethyan contraction to Eo-Alpine ("Austroalpine") nappe stacking that took place during the Early Cretaceous is an important event in the Cretaceous history of the AlpineCarpathian-Dinaridic orogenic system. The Transdanubian Range (TR) in Hungary has been shown to have been impacted by both events. Dating of this transition has proved to be difficult; several interpretations were published during the last decades. Uniquely exposed in and around the Gerecse Mountains, the Lábatlan Sandstone Formation (LSF) and the Vértessomló Aleurolite Formation (VAF) bracket this time interval. The last phase of Neotethyan contraction occurred after the deposition of the LSF, and the Eo-Alpine nappe stacking started during the deposition of the VAF. Earlier stratigraphical studies provided valuable data for our understanding of geodynamics, but precise bio- and chronostratigraphy - to constrain the interval of deformations - became possible only with systematic correlation of macrofossil-poor outcrops to ammonite-rich series with the help of calcareous nannofossil data. Here new nannofossil data, and whenever still available, a re-examination of the original smear slides yields new constraints on the age of the younger part of the sequence. The nannofossil and ammonite record is now combined to create a local chronostratigraphical correlation, with records tied in to the integrated Tethyan nannofossil and ammonite biozonation, which, in turn, is numerically calibrated by international zonal standards and radiometric ages. Our study demonstrates that the youngest part of the sandstone-dominated LSF is in nannozone NC7B of late Aptian age. The overlying Köszörükőbánya Conglomerate Member has a closely similar age in NC7A/B, noticeably older than previously suggested. On the other hand, the VAF clearly is of early Albian age (NC8). This latter unit is not represented in the inner Gerecse Mountains, in contrast to what has been suggested in previous studies. The observed earlier two sub-phases of Neotethyan compression with N-S to ENE-WSW shortening possibly are latest Aptian in age and are within nannofossil subzone NC7C, while the following Eo-Alpine deformation has an early Albian age (NC8) and is marked by W-E to NW-SE compression. The Aptian/Albian boundary (around $113 \mathrm{Ma}$ ) may indicate the switch of the TR from lower to upper position with respect to Neotethyan subduction to "Austroalpine" nappe stacking. Our data on deformational ages may support the idea that the onset of "Austroalpine" transpressional deformation at c. 114-112 myr ago could be related to the start of Penninic subduction, or, alternatively, to the onset of intra-oceanic subduction within the Austroalpine realm.
\end{abstract}

(c) 2018 Elsevier Ltd. All rights reserved.

\footnotetext{
* Corresponding author.

E-mail address: sziveso@nhmus.hu (O. Szives).
}

\section{Introduction}

Calcareous nannoplankton and ammonites are common and well-preserved fossils in Lower Cretaceous sedimentary units of the Transdanubian Range (TR). Since Hantken (1868), deposits of the 
Gerecse and the northernmost Vértes Mountains of the TR have been interpreted to have fundamentally different origins (Haas and Császár, 1987; Kázmér, 1988). In view of their unique nature, the exposed siliciclastic Cretaceous sediments of the Gerecse Mountains, and their subsurface continuations in the northwestern Vértes foreland, have always been in the focus of Hungarian stratigraphy and palaeontology (Somogyi, 1914; Fülöp, 1958, 1997; Báldi-Beke, 1963; Császár, 1986, 1995; Kázmér, 1987; Árgyelán, 1989, 1996; Sztanó, 1990; Bodrogi, 1992; Fogarasi, 1995, 2001; Bodrogi and Fogarasi, 2002; Sasvári, 2009; Főzy et al., 2013). Following earlier geodynamic models and advances in stratigraphy, intensive field work in the Gerecse Mountains during the last 25 years has provided new information on structural evolution (Bada et al., 1996; Csontos et al., 2005; Sasvári, 2008, 2009; Fodor and Fözy, 2013; Fodor et al., 2017, 2018). However, in order to draw geodynamic conclusions from these data sets more precise biostratigraphical knowledge of the Gerecse clastics sequence would be needed, particularly for its late stage.

From a structural point of view, the TR represents a particular unit within the Alpine-Carpathian-Dinaridic orogen, while its tectono-sedimentary evolution includes processes related to both Dinaric and Austroalpine domains (Tari, 1994; Schmid et al., 2008) (Fig. 1A). Mesozoic palaeotectonic reconstructions suggest that the TR was situated between two major oceanic domains, the Middle Triassic-Late Jurassic Neotethyan Meliata-Vardar and the Jurassic-Paleogene Piemont-Ligurian (South Penninic or Alpine Tethys) oceans (Fig. 1B, C) (Csontos and Vörös, 2004; Schmid et al., 2008; Handy et al., 2010). At present, the TR is surrounded by tectonic units derived from these oceans and their passive margins (Fig. 1A). However, its tectonic boundaries formed during consecutive deformation phases from the Late Jurassic to Early Miocene.

In consequence of its transitional Mesozoic palaeogeographical position, the tectonic evolution and related basin formation were controlled by both oceanic domains. This is particularly clear in Cretaceous basin evolution and connected deformation phases. During the Early Cretaceous, a clastic sedimentary basin evolved in the northern part of the TR, which represents a flexural basin (Császár and Árgyelán, 1994; Tari, 1994, 1995; Mindszenty et al., 1994, 2001). The loading nappe stack was derived from the obducted Neotethyan oceanic lithosphere and its imbricated passive margin (Fig. 1C). In this way, the TR shares a common geodynamic link with Dinaridic units located along its southeastern boundary (Fig. 1A).

On the other hand, the Late Cretaceous tectonic evolution of the TR is linked to the Austroalpine nappe system. This stack of nappes was essentially formed during the Late Cretaceous, and at present is situated to the north and west of the TR (Plašienka, 2003; Schmid et al., 2004) (Fig. 1C). Nappe stacking is part of the Eo-Alpine orogeny, which has an indirect geodynamical link with the subduction of the Piemont-Ligurian (Penninic) ocean (Fig. 1C) (Handy et al., 2010). Thus, the TR changed its position with respect to the subducting oceanic lithospheres. This fairly important switch in tectonic connections occurred during the mid-Cretaceous, during the final phase, or right after the Early Cretaceous foreland basin evolution of the northeastern TR. One important goal of the present paper is to provide precise biostratigraphy-based age constraints for this change, dating formations in relation with deformation phases.

On the basis of nannofossils - combined with ammonite data the main purpose of the present work is threefold. Firstly, to identify the age of certain sedimentary units represented by surface outcrops or wells with no available macrofossil record, which have not been precisely dated so far. Secondly, to update previously unpublished nannofossil biostratigraphical work for the area (Fogarasi, 2001), and lastly, to provide a more precise time frame for structural deformation phases of the clastic basin. Analysis on foraminifer and ostracod assemblages are also on the way, and a detailed ammonite stratigraphy for the area and its sedimentary units were provided previously by Fözy et al. (2002) and Szives (1999, 2002) and Szives et al. (2007).

The present paper holds the novelty of a revised subdivision of structural phases with respect to the combined nanno- and ammonite zones. These zones are calibrated to absolute time scales (Ogg et al., 2016), thus the suggested extent of deformation phases can be expressed in millions of years, which makes it comparable to other types of sources for deformation phases derived from neighbouring Alpine-Carpathian areas.

\section{Nannofossil research in the area}

The history of nannoplankton research of the Lower Cretaceous of Hungary is rather brief. The most influential Hungarian nannofossil micropalaeontologist has been Mária Báldi-Beke (1963, 1965; BáldiBeke in Fülöp, 1964, 1976; Báldi-Beke in Császár, 1986; Sztanó and Báldi-Beke, 1992). Later, Félegyházy (Félegyházy and Nagymarosy, 1991, 1992) and Fogarasi (Fogarasi, 2001; Fózy et al., 2002) started to work on the topic. Since then no nannofossil research was done on Lower Cretaceous sedimentary rocks in the TR.

\section{Geological setting}

\subsection{General background}

The Mesozoic sedimentary sequences of the TR reflect complex sedimentary and tectonic processes that occurred in the neighbouring Vardar-Meliata branch of the Neotethys Ocean and also in the Piemont-Ligurian Ocean (Császár and Árgyelán, 1994; Tari, 1994; Csontos and Vörös, 2004; Fodor and Fözy, 2013). Extensional tectonic movements connected to the Neotethyan breakup started in the Middle Triassic. Convergent tectonics became dominant from the late Middle Jurassic, related to intra-oceanic subduction and subsequent obduction of the Vardar ophiolites onto the passive Adriatic margin, possibly from the Middle Jurassic onwards (Schmid et al., 2008; Handy et al., 2010) (Fig. 1B, C).

Reflecting these processes, two different subbasins developed in the TR during the Early Cretaceous; the northeastern Gerecse siliciclastic basin and the southwestern maiolica carbonate basin (Fig. 1A) (Haas and Császár, 1987; Kázmér, 1988; Császár, 2002). These two subbasins were separated by an elevated high. The siliciclastic sedimentary units of the Gerecse Mountains represent the depocentre of the northeasterly subbasin, while the high to the southwest corresponds to the forebulge of a typical flexural foreland basin (Császár and Árgyelán, 1994; Tari, 1994; Mindszenty et al., 1994, 2001). The load for flexural deformation was the overriding Neotethyan Vardar ophiolites, although the distance between the obducted ophiolites and the TR was considerable. Petrographic work has demonstrated that such ophiolites represented a part of the source for the clastic input (Árgyelán, 1989, 1996; Vaskó-Dávid, 1991; Császár et al., 2008). Sedimentological research has determined sediment transport directions mainly from the northeast, subordinately from the east (Sztanó, 1990; Fogarasi, 1995). These directions are in agreement with the foreland basin model that postulated the source east or northeast of the TR, where ophiolites could have been present (see position of TR in Fig. 1A and C).

\subsection{The Early Cretaceous sedimentary cycle in the area}

The evolution of the Gerecse and Vértes foreland basins started during the earliest Cretaceous (Berriasian), when deposition of widespread maiolica limestones ceased. The earliest sign of a clastic source came with the deposition of the Felsővadács Conglomerate 
Member of the Bersek Marl Formation which contains basic magmatite and chert pebbles (Fülöp, 1958) and abundant chromespinell among heavy minerals. The source of the clasts was interpreted to have been the obducting Neotethyan oceanic lithosphere (Árgyelán, 1996; Császár and Árgyelán, 1994).

The 50-150-m-thick Bersek Marl Formation is predominantly a marly sequence with thin sandstone intercalations, which was deposited during the Valanginian-Hauterivian time interval. From the Barremian onwards, sandy input became dominant and led to deposition of the Lábatlan Sandstone Formation. The stratigraphy, geochemistry and fossils of the two units were intensively studied by Fülöp (1958, 1997), Fözy and Fogarasi (2002), Főzy and Janssen (2009) and Bajnai et al. (2017). In an isolated outcrop the lithostratigraphically different Köszörükőbánya Conglomerate Member (KbC) on top of the formation is exposed. The Lábatlan Lt-36 borehole drilled in this outcrop (named Köszörükőbánya) has revealed the connection of the $\mathrm{KbC}$ with the underlying Lábatlan Sandstone Formation. The $\mathrm{KbC}$ member is composed of sandstones and conglomerates and is interpreted as a high-density gravity flow that filled channels of a deep-sea fan (Sztanó, 1990; Császár et al., 2012; Sztanó et al., 2018). This event represents the end of foreland basin evolution in the eastern Gerecse Mountains. Its late Aptian-early Albian age (Sztanó and Báldi-Beke, 1992) has been debated; it is here considerably revised.

Along the western margin of the Gerecse Mountains, the Aptian-lowermost Albian Tata Limestone Formation was laid down onto erosional surfaces. Occasionally, at the base of this crinoidal limestone hardground-related pockets can be found that contain a diverse, albeit highly condensed fossil assemblage of late early Aptian to earliest Albian date (Szives, 1999; Szives et al., 2007), interpreted as intermittent sediments of a submarine environment (Görög, 1995; Szives, 2002) in contrast to the terrestrial hiatus stressed by Fülöp (1976).

In the early Albian, due to slow subsidence and transgression, deeper offshore sedimentation started in a small basin located in the western part of the Gerecse Mountains and in the Vértes foreland, which led to formation of the Vértessomló Aleurolite unit, a dark siltstone (Figs 10-11). This formation is a continuation of the underlying Tata Limestone Formation by an increase in the amount of silt. Its heteropic facies in the Vértes foreland basin is a pachyodontbearing limestone, the Környe Limestone Formation, which was interpreted as a shallow-marine reef sediment (Császár, 1986; Czabalay, 1995). The typical succession of the Vértessomló Aleurolite Formation was penetrated in the Vértessomló Vst-8, Tatabánya Ta-1462, Oroszlány 0-1881 and Agostyán Agt-2 boreholes. Due to new clastic input, the growth of the early Albian reef complex was terminated and the variable, clastic to carbonate Tés Claymarl Formation was laid downin terrestrial to brackish environments on top of the Környe Limestone and the westerly Vértessomló Aleurolite Formation and extended further to the southwest (Figs. 10-11) (Császár, 1978, 1995). A decrease in clastic sedimentary influx during the early late Albian, combined with a sea level rise, resulted in the formation of the rudist platform Zirc Limestone Formation of 20-200 metres in thickness (Császár, 2002). The presence of planktic foraminifera in its upper part indicates deepening, when a sea level rise together with an increased amount of terrigenous input, drowned the carbonate platform. From the late Albian to the Cenomanian an important, locally 500 metres thick sequence of the ammonitiferous Pénzeskút Marl Formation deposited (Fig. 11). Its fossil content indicates a deep, hemi-pelagic, open-marine environment (Scholz, 1979; Császár, 1986; Szives et al., 2007).

\subsection{Early Cretaceous structural evolution of the Gerecse Mountains}

Analysis of the Early Cretaceous structural evolution of the Gerecse is rather difficult because of poor outcrop conditions and the presence of several structural phases. Following early structural works by Bada et al. (1996), more recently, Sasvári (2008, 2009) and Fodor (2010) suggested that there were three contractional deformation phases to have occurred during the Aptian to Albian, during and after clastic foreland sedimentation (Fig. 2). Fodor et al. (2018) subdivided the evolution into three tectonic phases with six subphases, which can be compared to that outlined in earlier works, but they refined the subdivision of tectonic evolution will be shown later on Fig. 12.

Although there are slight deviations in shortening directions (compression), the main difference is in timing with respect to the termination of clastic sedimentation. Sasvári $(2008,2009)$ suggested that part of the deformation, namely his first phase, occurred during the early(?) Aptian Fig. 2.

He postulated a hiatus or a very low deposition rate within the Lt-36 borehole, prior to deposition of the KbC. He attributed an Aptian date to the missing interval that might correspond to a structural deformation phase. In contrast, Fodor et al. (2018) suggested continuous sedimentation up to the $\mathrm{KbC}$. The onset of the oldest Cretaceous deformation (D2b and D2c subphases) took place after clastic deposition ended in the Gerecse clastic basin. Following stratigraphic concepts, he attributed an earliest Albian date to the D2b-c subphases. In both concepts, this early deformation was connected to foreland basin evolution and also to formation of the forebulge and southwestern maiolica basin (Fig. 1) (Tari, 1994; Sasvári, 2009). The direction of compression could have been between the N-S to the ENE-WSW.

The second deformation phase (R1 of Sasvári, 2008; D3a-b of and Fodor et al., 2018), shown in Fig. 12, was a shortening with folding, the compressional axes of which ranged from $E-W$ to NW-SE and geodynamic connections strongly varying according to authors. The middle or late Albian to Cenomanian third phase with a NW-SE to NNW-SSE shortening (R3 of Sasvári, 2008; D3c of Fodor et al., 2018) undoubtedly marks the Late Cretaceous EoAlpine orogeny (Tari, 1994; Sasvári, 2008). According to several authors (e.g., Haas and Császár, 1987; Tari, 1994; Sasvári, 2008) the typical folded character of the central and southern TR is only due to the third phase (Fig. 12; marked R3, D3c). On the other hand, Fodor (2010) considered the second phase to mark the onset of regional folding in the TR (D3ab), while the third phase indicated additional shortening only. Thus, knowledge of the age of the first and second phase constrains the age of the foreland-related and subsequent Eoalpine deformations and also the change between the two major geodynamic events.

\section{Localities and general remarks}

Irtásdülö - This outcrop lies in the western Gerecse (co-ordinates: $18^{\circ} 23^{\prime} 01.94^{\prime \prime} \mathrm{E}, 47^{\circ} 41^{\prime} 46.59 .62^{\prime \prime} \mathrm{N}$ ). The fine-grained marly sequence lies above the bulk of a sandstone unit, although a few metres of sandstone cover the marlstone. The site was earlier interpreted to represent the Vértessomló Aleurolite Formation.

Iván halála - This outcrop (co-ordinates: $18^{\circ} 23^{\prime} 33.19^{\prime \prime} \mathrm{E}, 47^{\circ} 42^{\prime}$ $53.70^{\prime \prime} \mathrm{N}$ ) exposes sandstone, but geophysical data seem to indicate intercalation with fine-grained strata (Zalai et al., 2015).

DSZM-046 outcrop (co-ordinates: $18^{\circ} 25^{\prime} 58.14^{\prime \prime}$ E, $47^{\circ} 43^{\prime} 51.39^{\prime \prime}$ $\mathrm{N}$ ) - samples (numbered DSZM-046/1-2) were taken from a small valley in the northern Gerecse from a grey, silty claymarl which was expected to represent the Vértessomló Aleurolite Formation on the basis of dip data and geophysical measurements (Zalai et al., 2015), but present nannofossil investigations refute this option and date these rocks as Aptian.

Szél-hegy - these outcrops expose a fine-grained siltstone just above some sandstone layers of the Lábatlan Formation (numbered as 2014-02-18 and 2014-03-04; co-ordinates: $18^{\circ} 27^{\prime} 30.17^{\prime \prime}$ E $47^{\circ}$ 


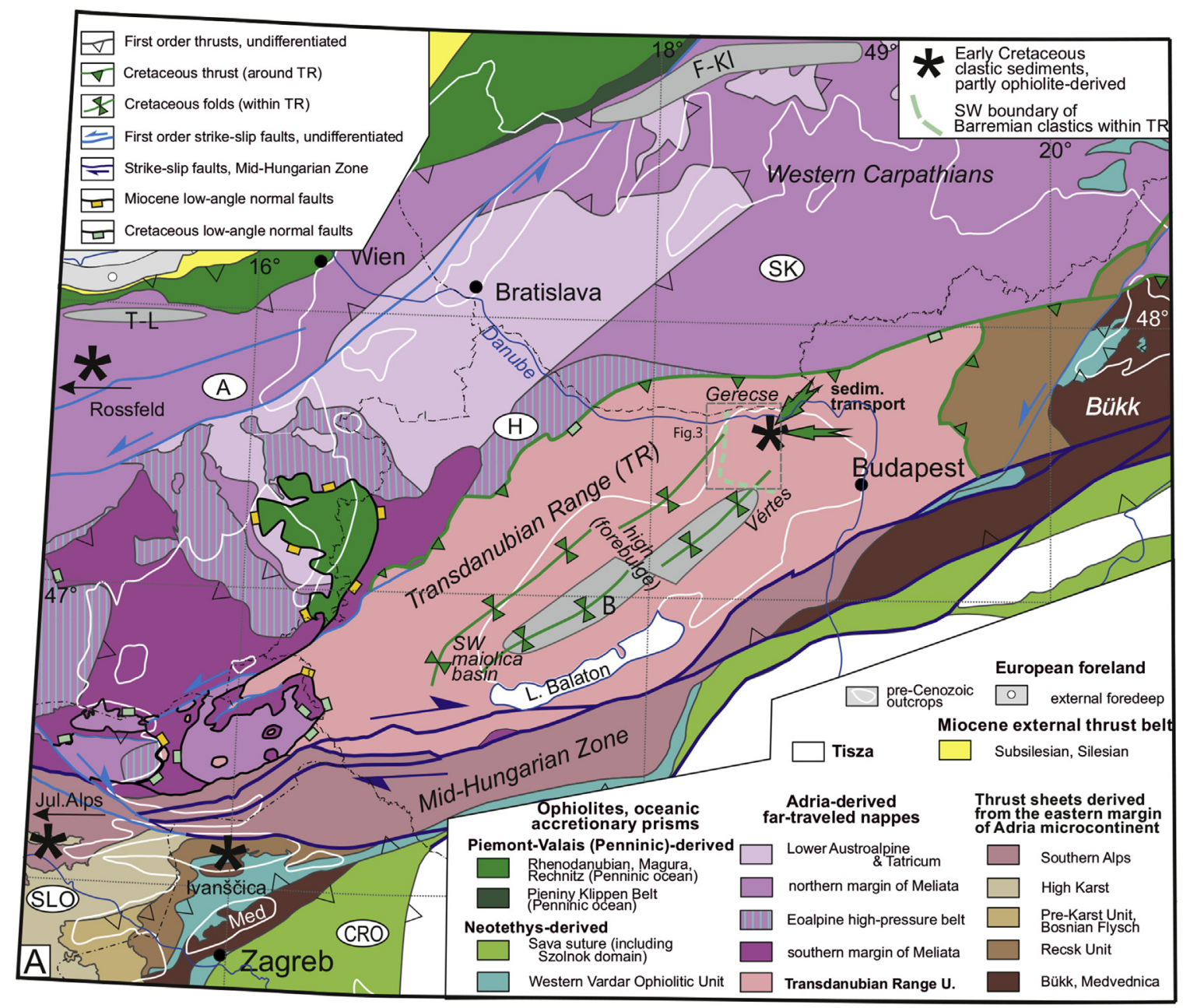

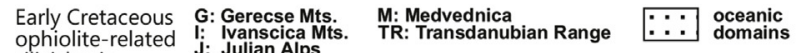
$\begin{array}{lll}\text { Ophiolite-related } & \text { j: Julian Alps } \\ \text { siliciclastic } & \text { R: Rossfeld }\end{array}$
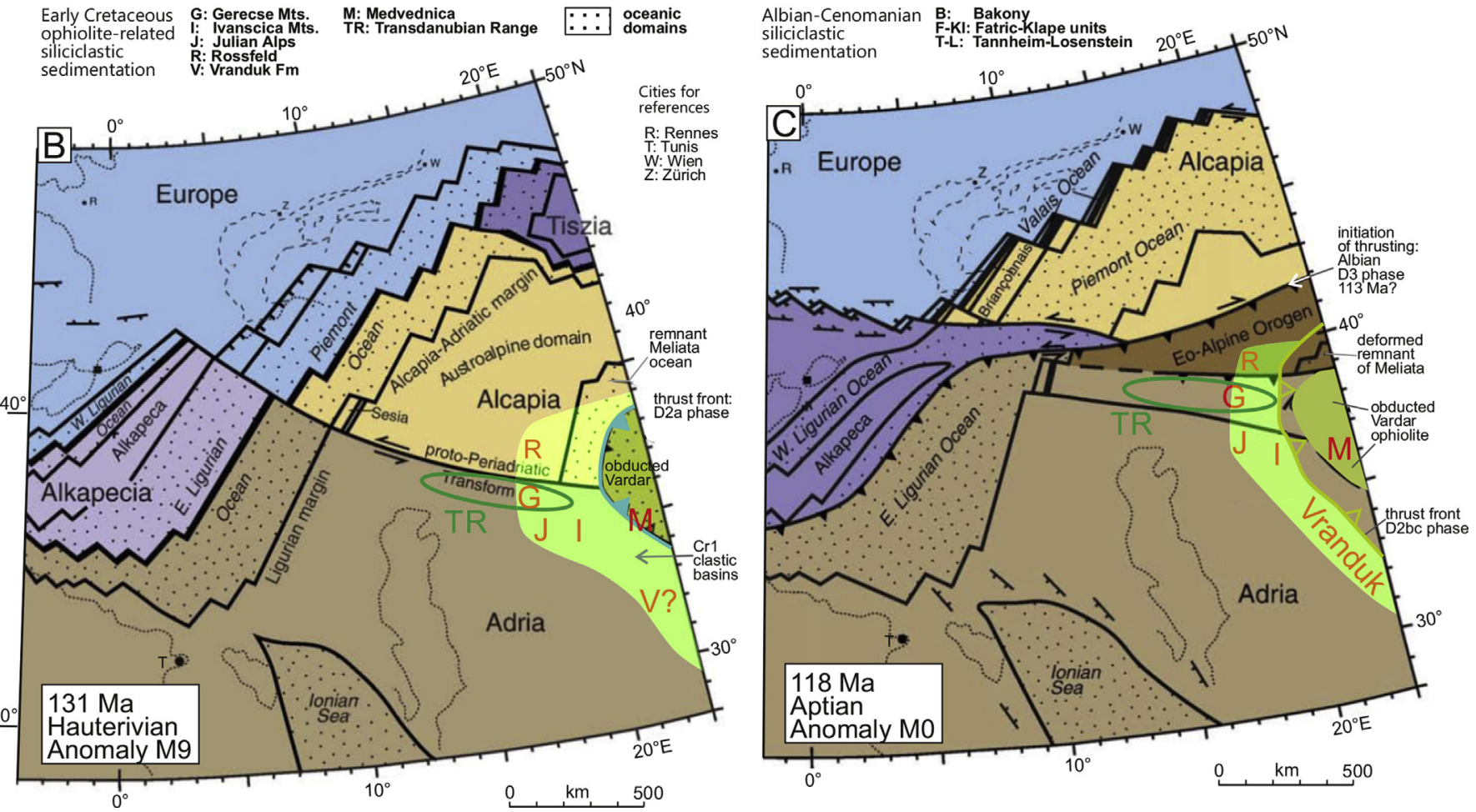

Fig. 1. A. Tectonic sketch of the Transdanubian Range (TR) and its surroundings (after Schmid et al., 2008; modified by Fodor et al., 2017). Locations of Early Cretaceous clastics after Faupl and Wagreich (1992), Goričan et al. (2012) and Lužar-Oberiter et al. (2012); the Albian-Cenomanian Tannheim-Losenstein Basin after Wagreich (2001, 2003). Note that the 


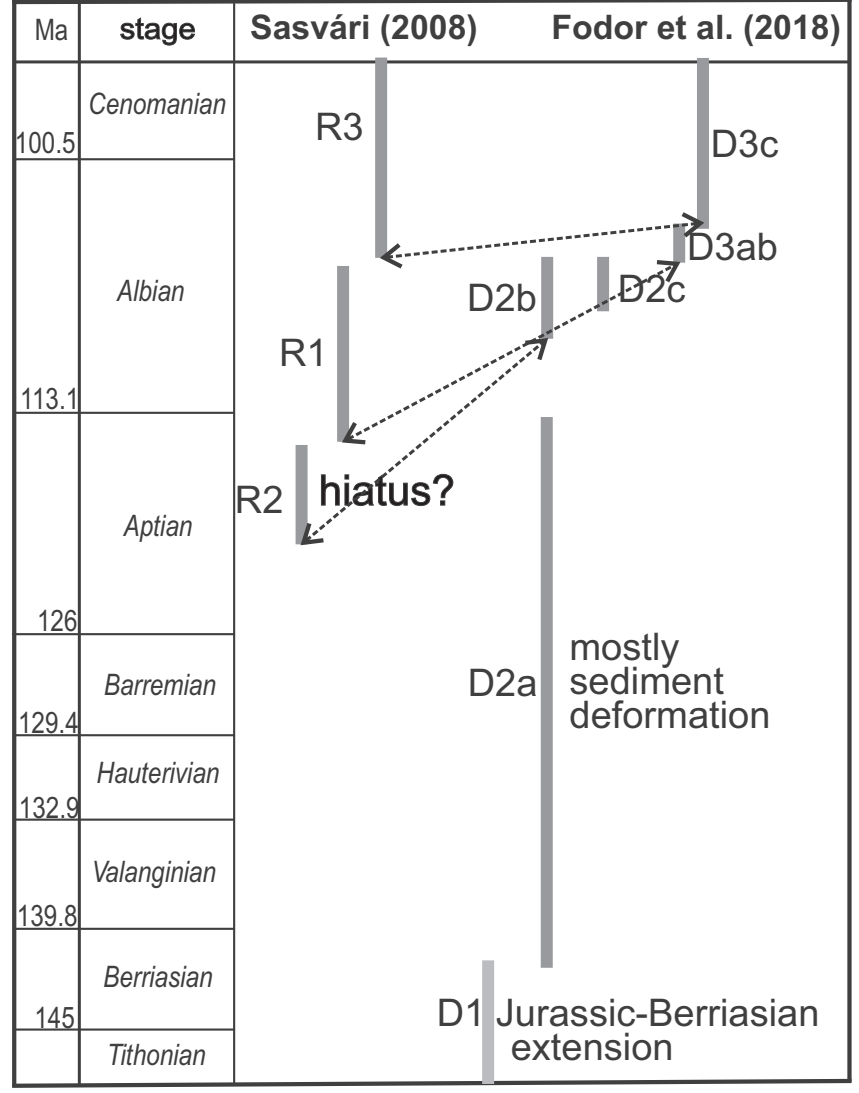

Fig. 2. Previous concept and postulated ages of Early Cretaceous deformation phases in the Gerecse Mts. Dashed lines indicate the possible correlations of the onset of the deformation phases. Note that the revised versions of the age of deformation phases are given after the biostratigraphical chapters, on Fig. 12.

$40^{\prime} 15.72^{\prime \prime} \mathrm{N}$ and $\left.18^{\circ} 27^{\prime} 33.52^{\prime \prime} \mathrm{E}, 47^{\circ} 40^{\prime} 19.11^{\prime \prime} \mathrm{N}\right)$. These rocks were literally attributed to the early Albian Vértessomló Aleurolite Formation (Sztanó et al., 2018) on the basis of lithological aspects, but without any palaeontological evidence.

Hajós-árok - this outcrop (co-ordinates: $18^{\circ} 28^{\prime} 37.87^{\prime \prime} \mathrm{E}, 47^{\circ} 42^{\prime}$ $24.82^{\prime \prime} \mathrm{N}$ ) exposes sandstones with calcareous intercalations; these were assigned to the Lábatlan Sandstone Formation by Fülöp (1958). Sedimentological characters have recently been revised by Sztanó et al. (2018). In the uppermost part of the outcrop, conglomerate intercalations can be observed; these may appear similar to the Köszörükőbánya Conglomerate Member of the Lábatlan Sandstone Formation.

Kálvária-domb or Tata (co-ordinates: $18^{\circ} 19^{\prime} 03.56^{\prime \prime}$ E, $47^{\circ} 38^{\prime}$ $21.74^{\prime \prime} \mathrm{N}$ ) is a classic locality of Hungarian geology (Fülöp, 1976; Haas and Hámor, 2001), at which the crinoidal Tata Limestone Formation overlies the Jurassic-Lower Cretaceous maiolica limestone. In between these units submarine hardground-related pockets were found, infilled with a huge amount of glauconitised or phosphatised macrofossil internal moulds. Ammonites from the Epicheloniceras martini to Hypacanthoplites jacobi standard Mediterranean Ammonite Zones (SMAZ), of early late Aptian to earliest Albian age (sensu Kennedy et al., 2000) have been described (Szives, 2002; Szives et al., 2007).
Köszörüköbánya - at this outcrop (co-ordinates: $18^{\circ} 30^{\prime} 19.38^{\prime \prime} \mathrm{E}$, $47^{\circ} 44^{\prime} 40.67^{\prime \prime} \mathrm{N}$ ), rocks represent the top part of the Lábatlan Sandstone Formation; in other words, the youngest exposed part of the Lower Cretaceous clastic sequence in the Gerecse Mountains (Figs. 3, 10, 11). The Köszörükőbánya Conglomerate (KbC) Member is part of a coarsening-upward clastic sequence of the Lábatlan Sandstone Formation and is underlain by sandstones and siltstones, which has been determined in the Lábatlan Lt-36 well which was drilled here. The KbC conglomerate was interpreted as a submarine channel of a deep-sea fan and, on the basis of nannofossils, it was assigned an early Albian (NC8 zone) date (Sztanó and Báldi-Beke, 1992). Fogarasi (2001) had no smear slides from this outcrop available; he used data supplied by Báldi-Beke (Sztanó and Báldi-Beke, 1992).

Lábatlan Lt-36 borehole (co-ordinates: $18^{\circ} 30^{\prime} 24.87^{\prime \prime}$ E, $47^{\circ} 44^{\prime}$ $36.57^{\prime \prime} \mathrm{N}$ ) - this was sunk at the locality of Köszörükőbánya. In its uppermost part, a c. 30-m-thick, fine-grained deposit of silty sandstone and siltstone of the Lábatlan Sandstone Formation was penetrated.

Neszmély N-4 borehole (co-ordinates: $18^{\circ} 23^{\prime} 54.15^{\prime \prime}$ E, $47^{\circ} 44^{\prime}$ $\left.19.82^{\prime \prime} \mathrm{N}\right)$ - this penetrated the Lábatlan Sandstone Formation down to a depth of 421 metres. Between 156.0 and 351.0 metres, a rich ammonite assemblage was found (Horváth, 1978a, b).

Tatabánya Ta-1462 borehole (co-ordinates: $18^{\circ} 38^{\prime} 45.24^{\prime \prime} \mathrm{E}, 47^{\circ}$ $57^{\prime} 9.23^{\prime \prime} \mathrm{N}$ ) - this borehole was drilled in 1962 and penetrated the Vértessomló Aleurolite Formation to a depth of 382.2 metres in the town of Tatabánya.

Vértessomló Vst- 8 borehole (co-ordinates: $18^{\circ} 22^{\prime} 46.19^{\prime \prime}$ E, $47^{\circ}$ $30^{\prime} 27.43^{\prime \prime} \mathrm{N}$ ) - this was sunk in the northern part of the Vértes Mountains (Császár, 1995, 2002). The sequence starts with the crinoidal Tata Limestone Formation, then grading upwards into a fine-grained sequence classically attributed to the early Albian Vértessomló Aleurolite Formation (Császár, 1996) with intercalation of the pachyodont-bearing Környe Limestone Formation. Albian rocks were overthrust by the Tata Limestone Formation.

Agostyán Agt-2 borehole (co-ordinates: $18^{\circ} 21^{\prime} 44.01^{\prime \prime} \mathrm{E}, 47^{\circ} 39^{\prime}$ $59.93^{\prime \prime} \mathrm{N}$ ) - this penetrated a massive thickness of 400 metres of Vértessomló Formation (Császár, 1985). Its importance is the huge thickness of the same sedimentary formation, representing a relatively short time period.

Oroszlány 0-1881 borehole (co-ordinates: $18^{\circ} 20^{\prime} 55.23^{\prime \prime} \mathrm{E}, 47^{\circ}$ $30^{\prime} 9.44^{\prime \prime} \mathrm{N}$ ) - this also penetrated the Vértessomló Formation and contains a fragment of the ammonite zonal index, Douvilleiceras mammillatum, at a depth of 338.4 metres, as published by Szives et al. (2007, p. 78, pl. 25, fig. 3). Thus, this unit can be placed in the Douvilleiceras mammillatum SMAZ. Preparation of smear slides was not deemed necessary, because on the basis of this ammonite its age could be determined precisely.

The Bersek Hill sections (Fözy, 1995; Bajnai et al., 2017) are beyond the scope of the present study for two reasons: they are older, i.e., up to the Toxancyloceras vandenheckii SMAZ, in contrast to younger sections investigated for the present study the age of which correspond to the Martellites sarasini SMAZ. Besides, detailed integrated ammonite, nannofossil and belemnite data of Bersek Hill were previously published by Fözy and Fogarasi (2002) and Fözy and Janssen (2009).

\section{Material and methods}

We sampled outcrops and borehole intervals where the presence of the upper part of the clastic Lower Cretaceous sequence, the upper

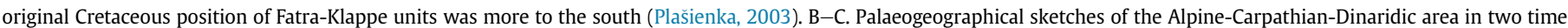

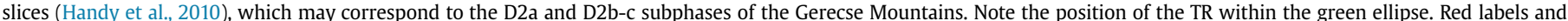
green patches refer to Early Cretaceous clastic basin remnants and for the possible extent of the foreland basin. Medvednica (M) was located below the ophiolite sheet. 


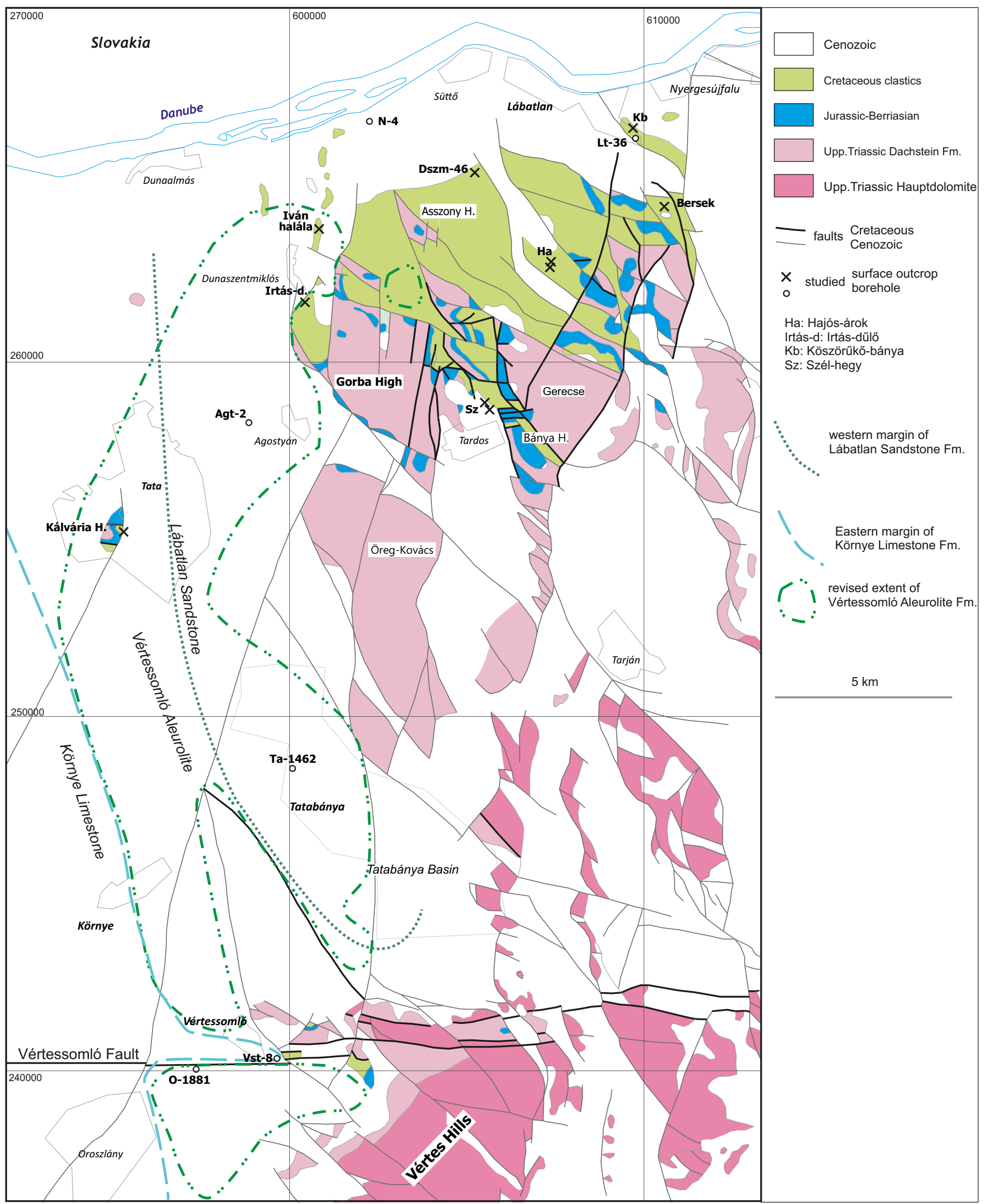

Fig. 3. Geological map of the Gerecse and northern Vértes Mountains (Fodor and Fözy, 2013), showing the localities and boreholes mentioned in the text. 

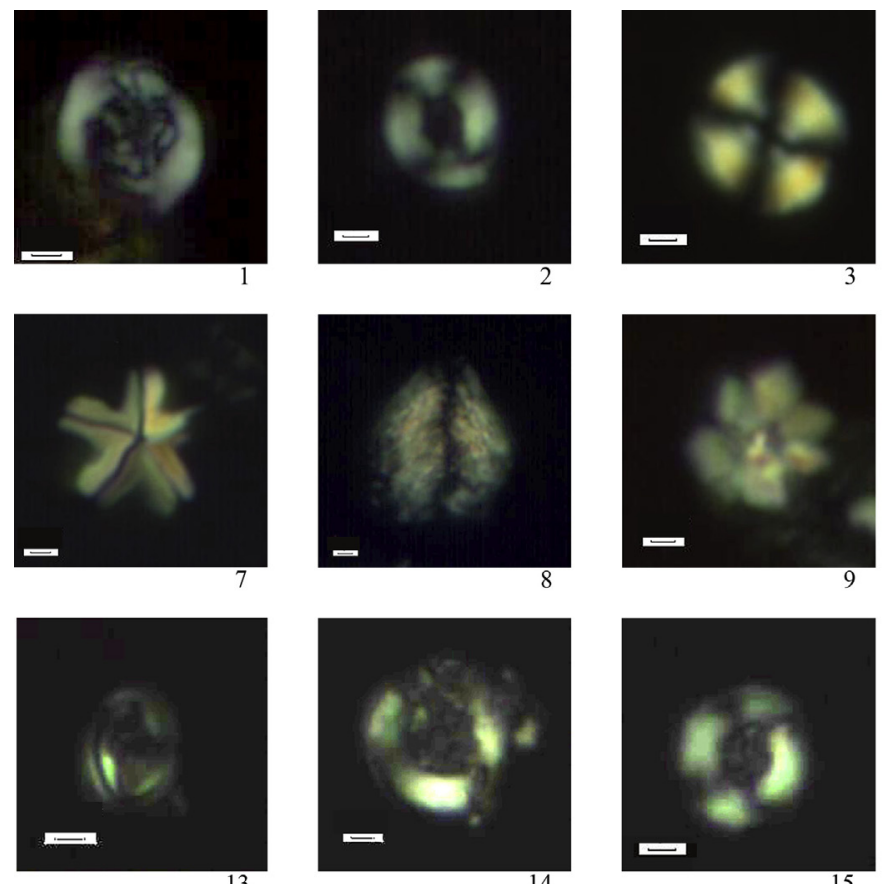

14

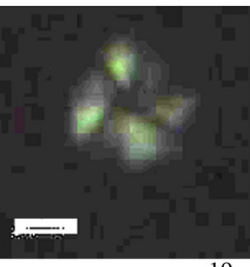

19

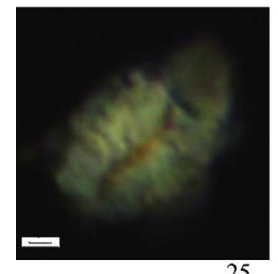

25

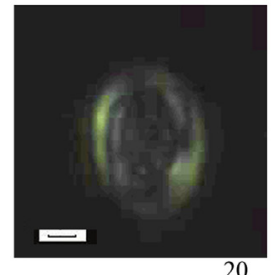

20

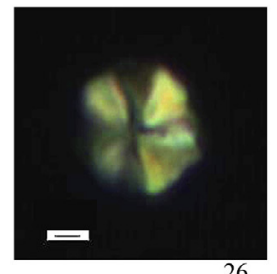

26
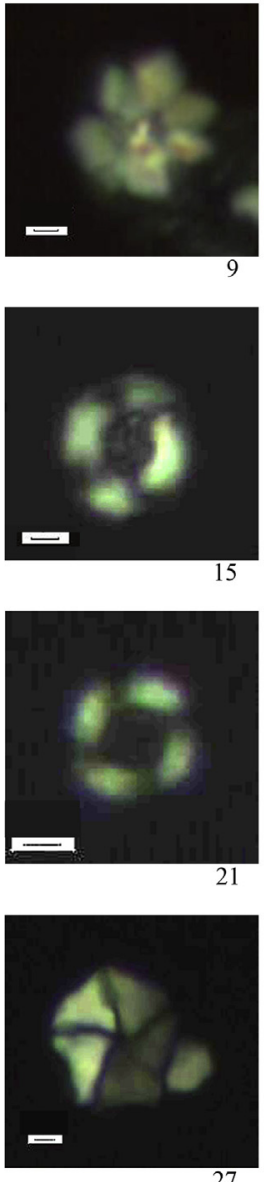


16

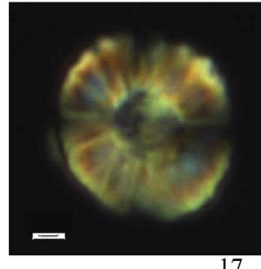

17
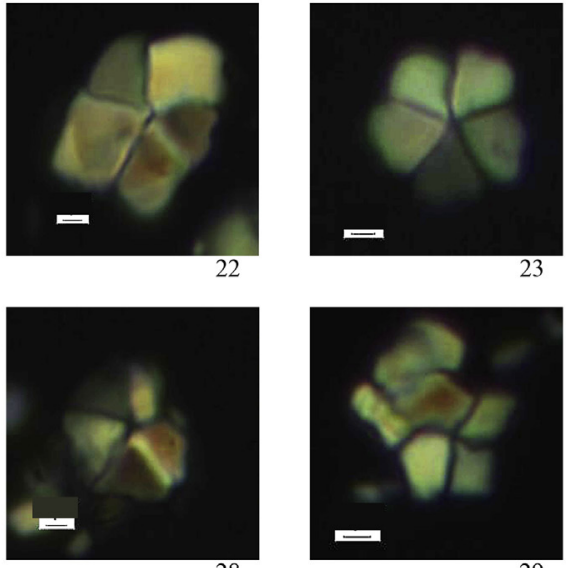
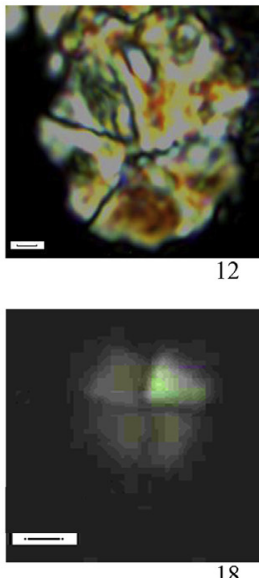

18
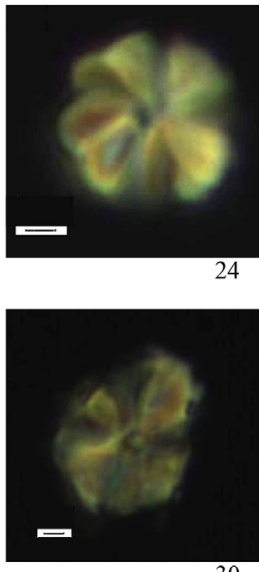

30

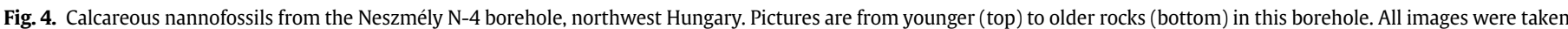

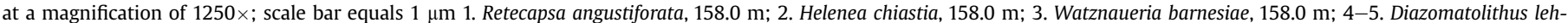

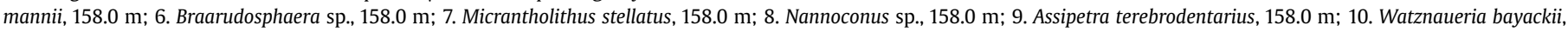

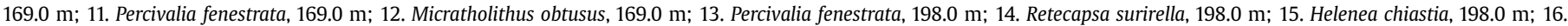

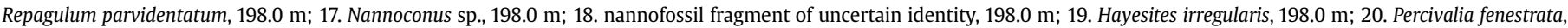

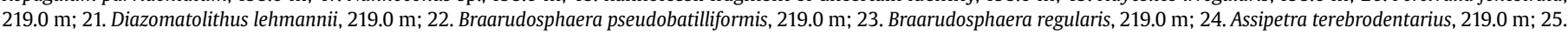

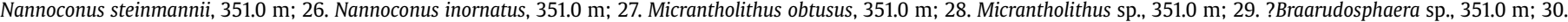
Assipetra terebrodentarius, $351.0 \mathrm{~m}$.

part of the Lábatlan Sandstone Formation, could be postulated (i.e., N4 borehole, Iván halála, Hajós-árok and Köszörükőbánya outcrops). In addition, the previously assumed occurrences of the early Albian Vértessomló Aleurolite Formation (Irtásdülö, DSZM-46, Szél-hegy) are also investigated here for the first time in order to determine their exact age. The boreholes Vst-8, Ta-1462 and O-1881 were re-sampled (Fig. 3) and available ammonite data are combined with nannofossils. Analyses of ammonite faunas were carried out previously for boreholes that penetrated the deeply buried Vértessomló Aleurolite Formation (Szives et al., 2007, pp. 34-42) and the underlying crinoidal limestone unit (Tata Limestone Formation) at various localities in the northwestern Vértes foreland (Szives et al., 2007, p. 78).

New smear slides were prepared for Irtásdülő (1), Iván halála (1), the outcrop DSZM-46 (5), Szél-hegy (4), core material of boreholes Lt-36 (1), N-4 (9), Vst-8 (10) and Agt-2 (1), following the smear slide technique described by Bown and Young (1998). The original smear slides of Báldi-Beke (Sztanó and Báldi-Beke, 1992) from KbC (6) and of Fogarasi (Fogarasi, 2001; Főzy et al., 2002) from borehole Lt-36 (12) were also re-examined. Smear slides (34) of the Vst- 8 borehole and the Hajós-árok (8) and Tata Kálvária-domb (5) localities investigated by Fogarasi (2001) must be considered lost.

A quantitative nannofossil analysis is beyond the scope of the present paper, although, based on work by Herrle and Mutterlose (2003), three basic quantitative classes were used to measure nannofossil abundances, as follows: common: more than 1 specimen per field of view (FOV), frequent: 1 specimen per 2-10 FOV, rare: 1 specimen per 11 FOV. Data sheet of nannofossil abundances including all localities is attached as a Supplementary Appendix 1. Ammonite and nannofossil taxa cited in the text are listed in the Supplementary Appendix 2 in order of classification (Bown and 

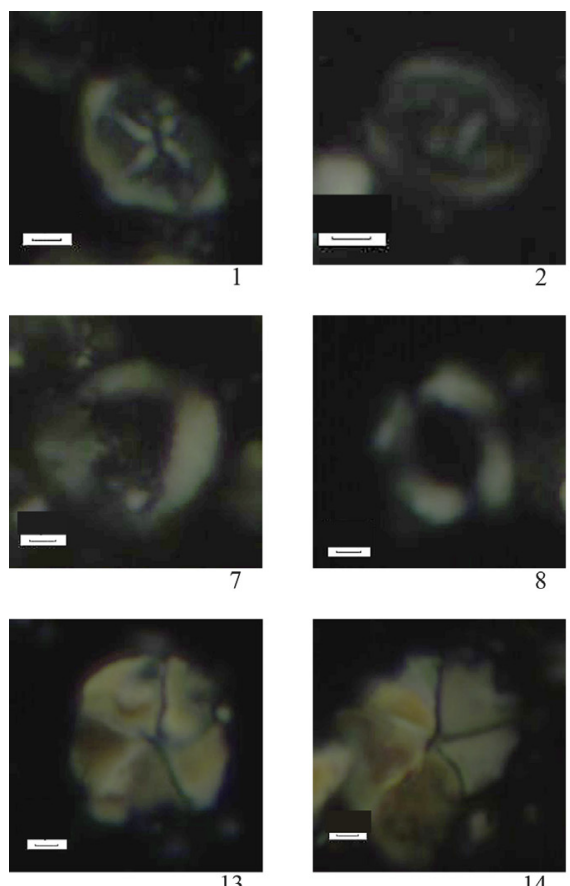

14
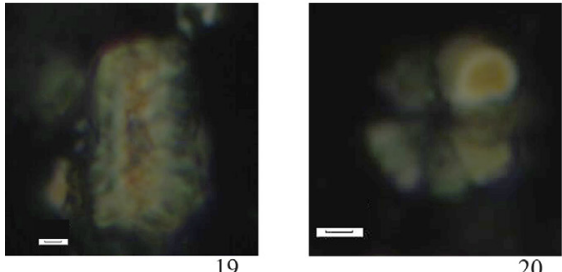

20

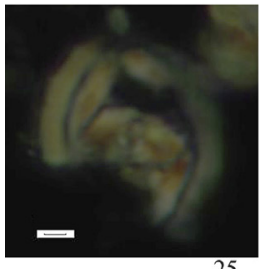

25

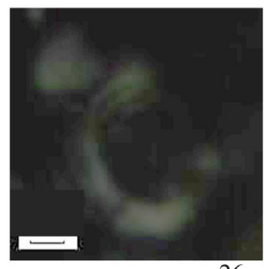

26
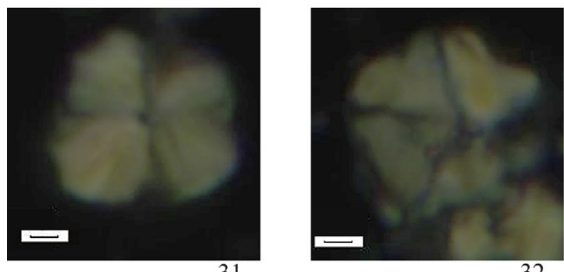
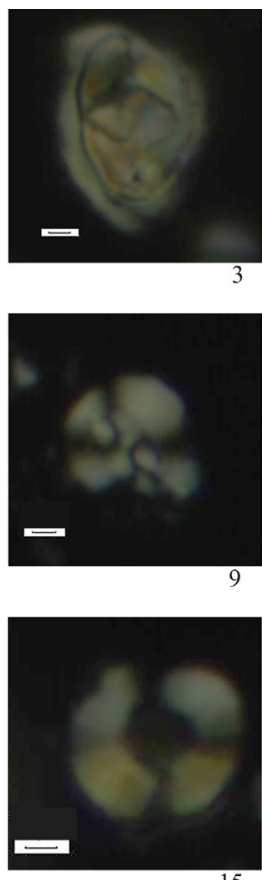

15

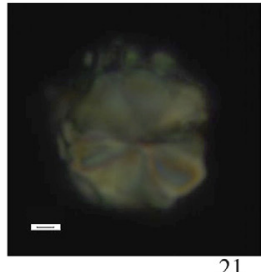

21

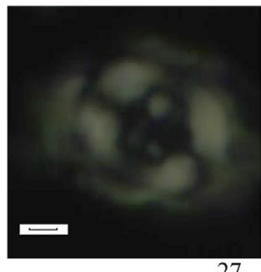

27

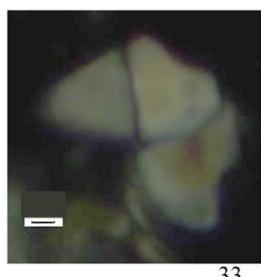

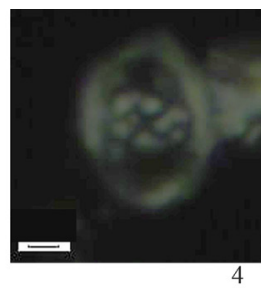
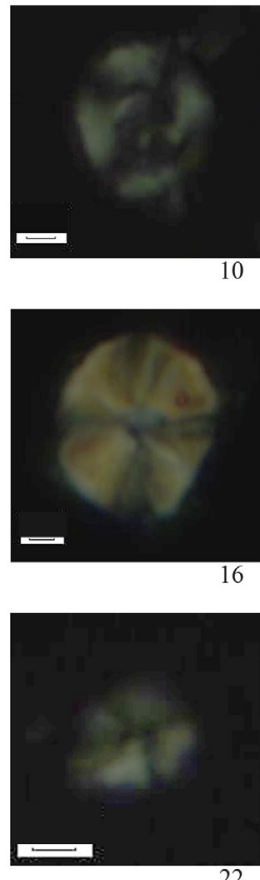

22

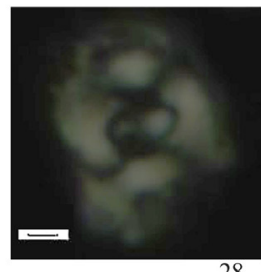

28

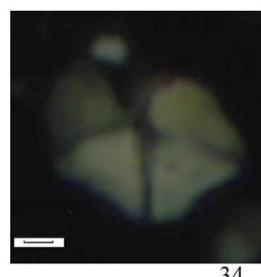

34
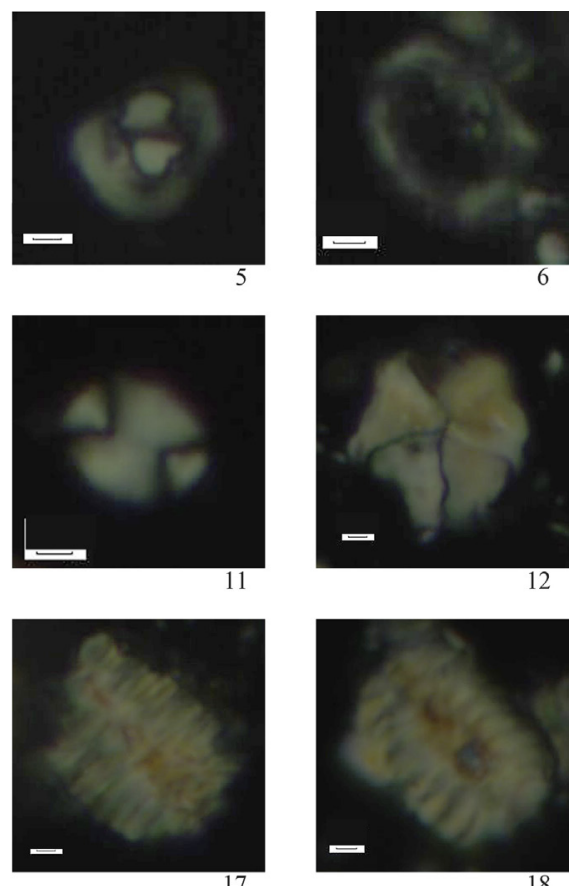

17

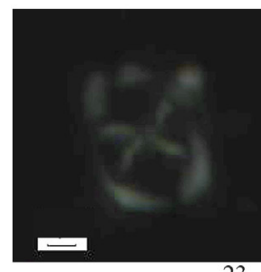

23

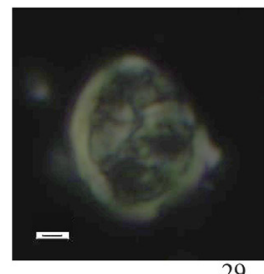

29

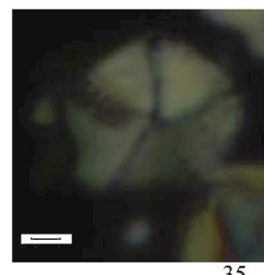

35

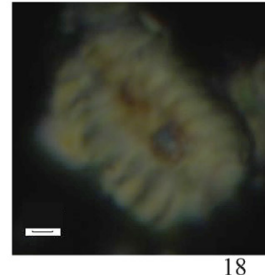

18
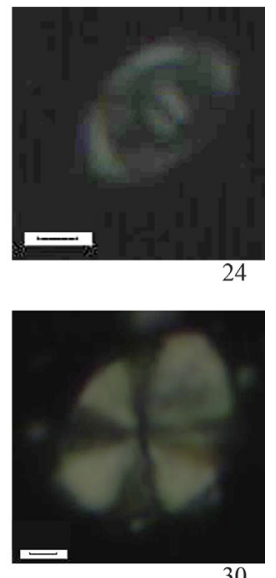

30

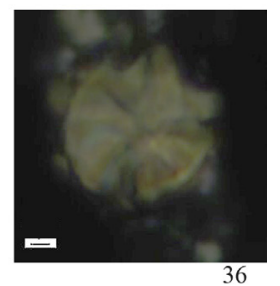

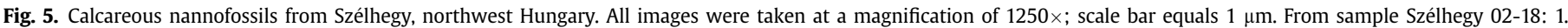

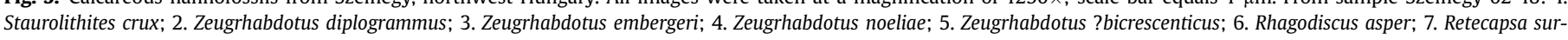

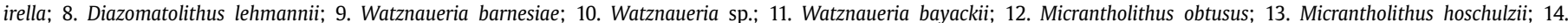

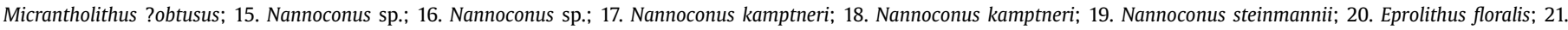

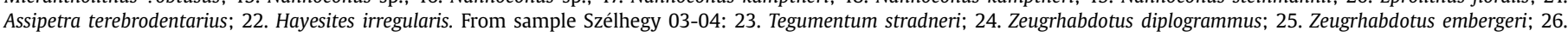

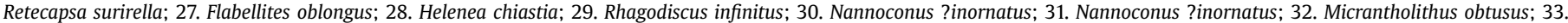
Micrantholithus obtusus; 34. Micrantholithus obtusus; 35. Micrantholithus hoschulzii; 36. Assipetra terebrodentarius.

Young 1997); ammonite nomenclature follows Wright et al. (1996), while the taxonomy of nannofossil taxa is adopted from the Nannotax3 website (Young et al., 2014).

Calcareous nannofossils are rare to common and moderately to well preserved in the smear slides studied. Photographs were taken with a Nikon Eclipse 50iPol microscope at a magnification of $\times 1250$ and a MediaCybernetics Evolution MP Colour digital microscope camera.

The smear slide collections of both Báldi-Beke and Fogarasi are housed in the Micropalaeontological Collections of the Hungarian Natural History Museum (HNHM, Budapest). Here, the newly prepared ones are also deposited. 

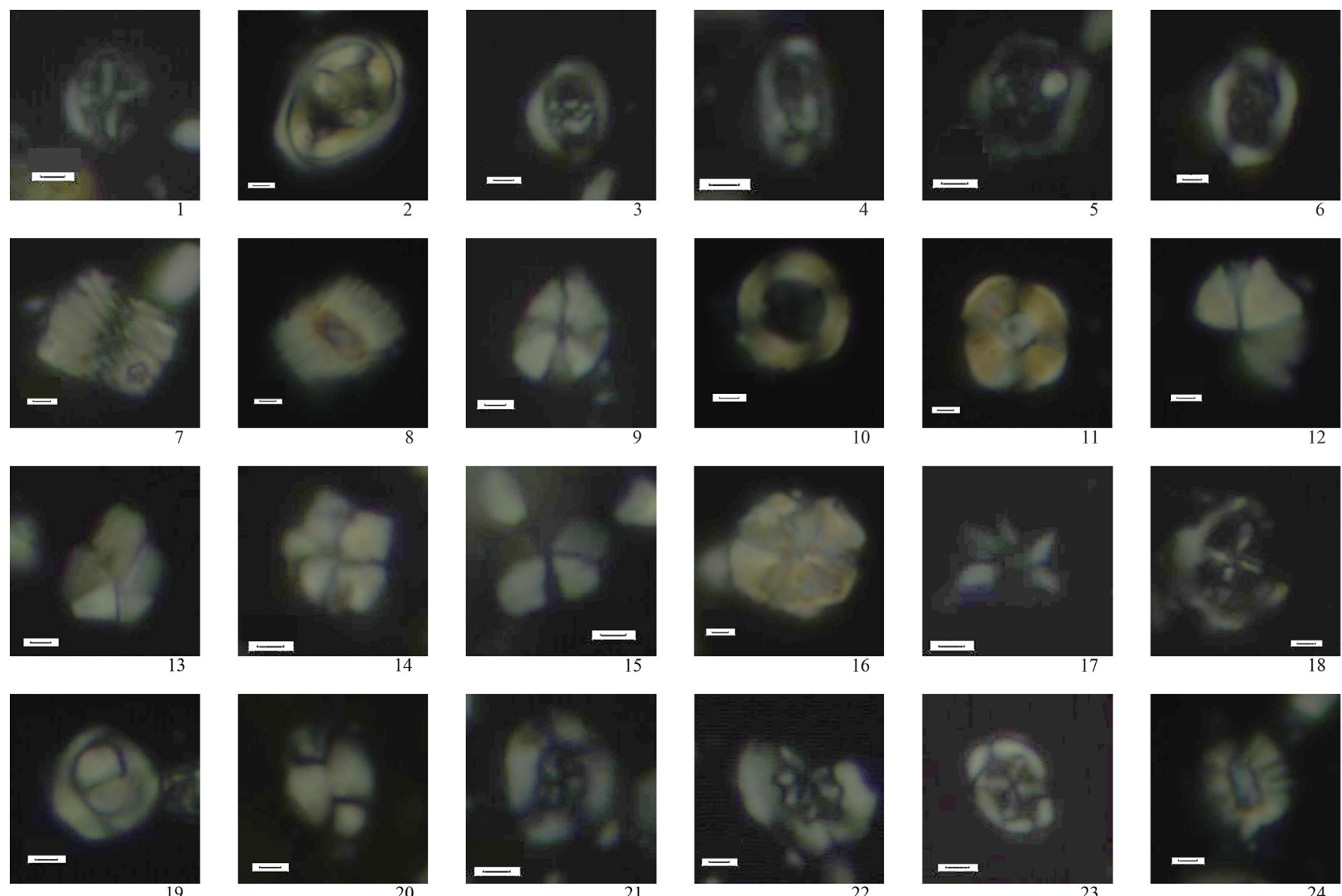

23
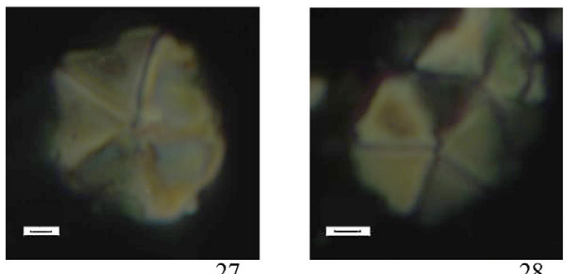

28
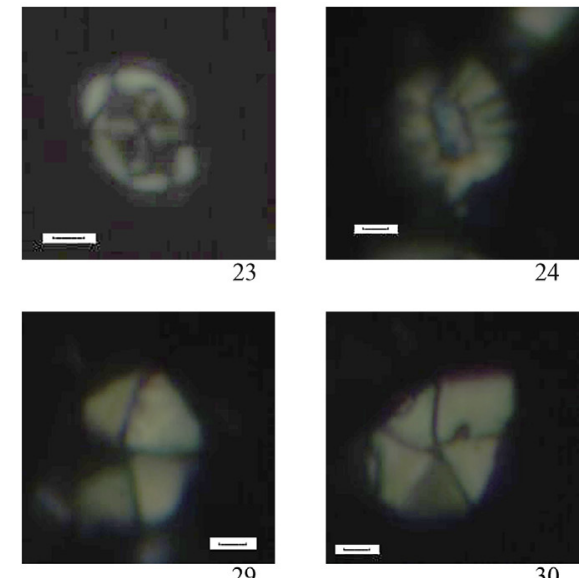

24

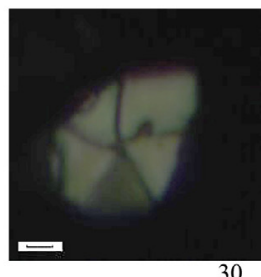

30

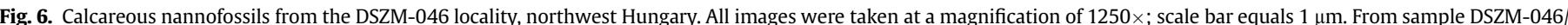

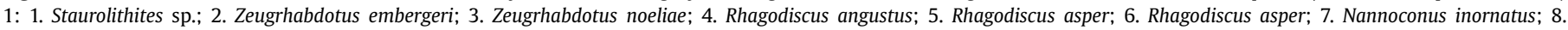

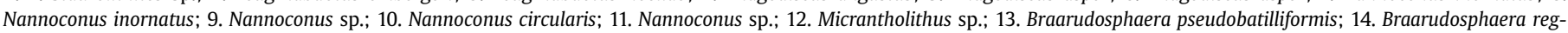

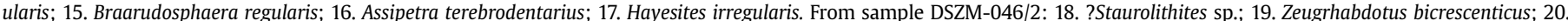

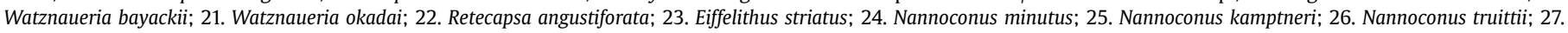
Micrantholithus obtusus; 28. Micrantholithus hoschulzii; 29. Micrantholithus hoschulzii; 30. Micrantholithus hoschulzii.

\subsection{Comments on nannofossil and ammonite biostratigraphy}

\subsubsection{Nannofossil zonation}

Due to the former low-latitude geographical position of the sedimentary sequences of the TR examined (Csontos and Vörös, 2004), we here use Tethyan zonations which follow Bown et al. (1998) and the Geological Time Scale (GTS; Ogg et al., 2016). The latter is a compilation of several sources, including Roth (1978), Bralower et al. (1995) and Bown in Kennedy et al. (2000, 2017). The GTS also provides an integrated chart of biozonations, together with magnetostratigraphy. In addition, Mahanipour et al. (2011, fig. 7) summarised BarremianAptian nannofossil zonations currently in use.

\subsubsection{Ammonite zonation}

Standard Mediterranean Ammonite Zones (SMAZ) are used here (compare Reboulet et al., 2014, 2018), with the exception of the upper Aptian Hypacanthoplites jacobi Zone (sensu lato), which is based on Kennedy in Kennedy et al. (2000, p. 601) and has been adopted by the latest version of the GTS. The Barremian/Aptian boundary still is problematic on the basis of ammonites due to taxonomic debates (Frau et al., 2017; Reboulet et al., 2018).

\subsubsection{The Aptian/Albian boundary ( $A A B)$ problem}

During the past two decades intensive integrated research on the Aptian/Albian boundary (AAB) has been carried out (Hart et al., 1996; Kennedy et al., 2000, 2014; Hancock, 2001; Owen, 2002; Petrizzo et al., 2012). Recently, Kennedy et al. (2014) have summarised the results and remaining problems. In 2016, the GSSP of the AAB was ratified (Kennedy et al., 2017).

According to Kennedy et al. (2000), the upper Aptian H. jacobi SMAZ extends to above the AAB, which means that the top of the $H$. jacobi SMAZ does not correspond either to the base of the Albian, 

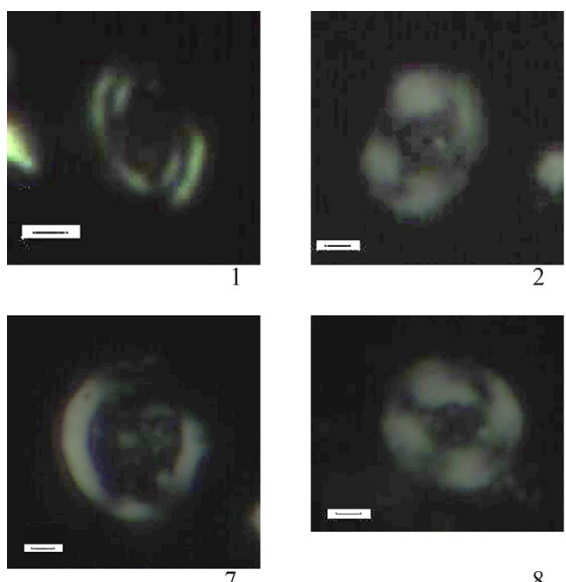

8
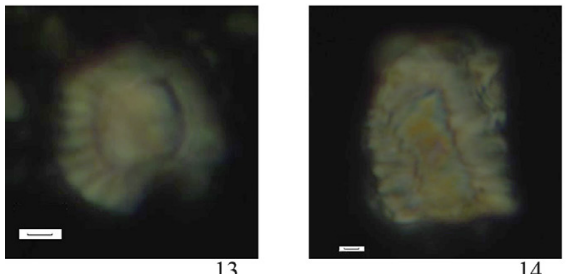
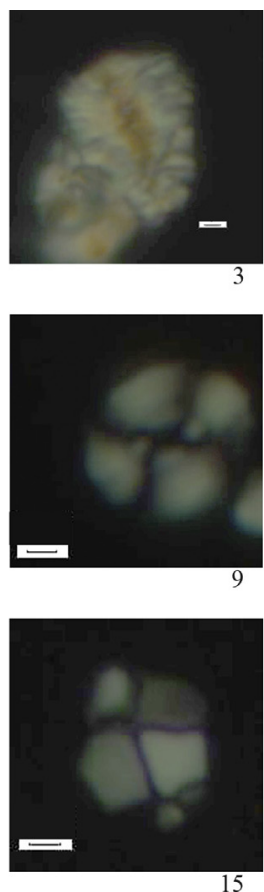
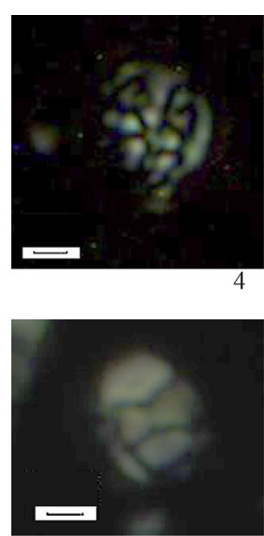

10

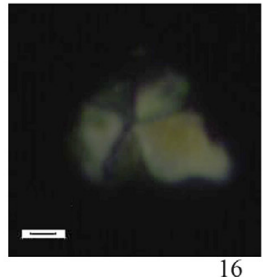

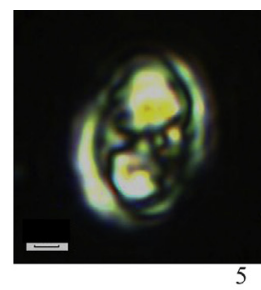
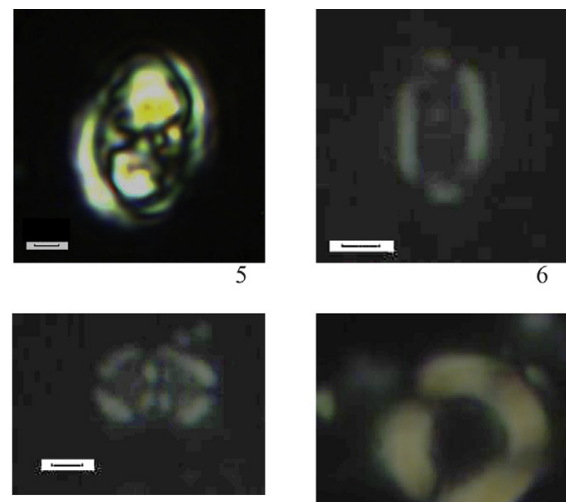

11
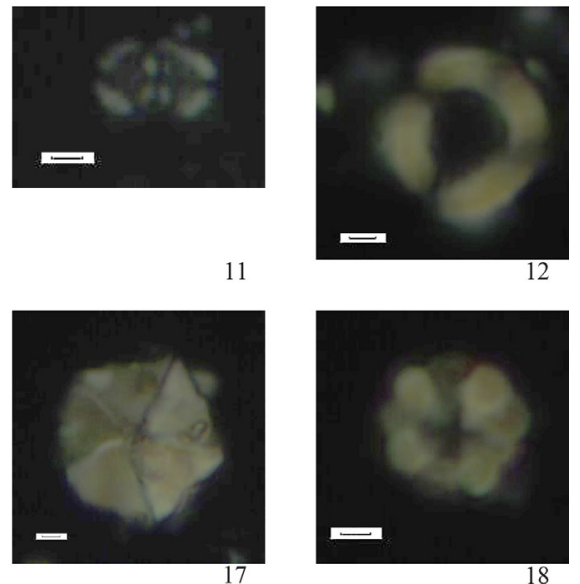

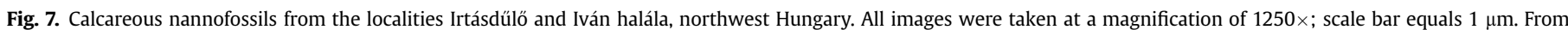

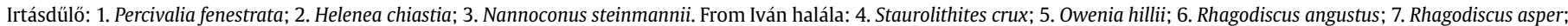

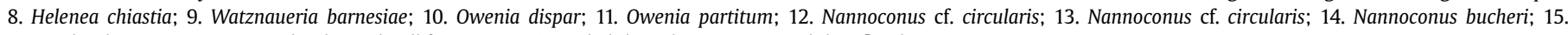
Braarudosphaera sp.; 16. Braarudosphaera batilliformis; 17. Micrantholithus obtusus; 18. Eprolithus floralis.

nor the base of nannofossil zone NC8. An integrated zonation of relevant sections in the Vocontian Basin, as published by Herrle and Mutterlose (2003), also supports this view. According to Bown (in Kennedy et al., 2000, fig. 29), the first occurrence (FO) of Prediscosphaera columnata (circular) postdates the last occurrence (LO) of Leymeriella tardefurcata, which fact was not adopted in the GTS.

In addition, the most recent geomagnetic data (Ogg et al., 2016) define the base of MOR as the base of the Aptian at 126.3 Ma, which is 3 myr older than in the previous versions of the time scale.

On the basis of nannofossils, Bown (in Kennedy et al., 2000, p. 617-621) summarised his opinion as follows, 'The FO of the genus of Prediscosphaera (P. spinosa) lies somewhere in the upper Lower Aptian (Neohibolites ewaldi belemnite Zone) and thus cannot be used to solve the Aptian/Albian boundary problem'. Bown discussed the evolutionary lineage and FO of Prediscosphaera spp. in detail and concluded that, ' $P$. columnata sensu stricto (with circular rim) can remain as a proxy as the boundary marker itself, which idea was later retained by Kennedy et al. (2014), but with lesser confidence. Besides, as Bown (in Kennedy et al. 2000, p. 619) emphasised: ' ... I am confident the lowest P. columnata at PréGuittard is low in the jacobi ammonite Zone in the upper Upper Aptian'. For this reason, the base of nannozone NC8 does not correspond to the AAB.

The position of the boundary is of special interest in the Vst- 8 and Ta-1462 boreholes, as well as at the outcrops of Tata Kálvária-domb and Köszörükőbánya.

\section{Results}

Our aim was to calibrate the best possible age of the rocks sampled so as to clarify certain sedimentary units and the timing of tectonic movements and structural deformations. However, palaeobiogeographical and palaeoecological implications, as based on nannofossils, are beyond the scope of the present paper. Every locality or borehole is described according to zone or subzone that either represents the longest, or the more likely time interval of the sequence sampled.

\subsection{Biostratigraphy}

Unless indicated otherwise, data from Young et al. (2014) are used here for the first (FO) and last occurrences (LO) of taxa.

\subsubsection{Flabellites oblongus Zone (NC5), upper Hauterivian-upper Barremian}

This zone is defined as the interval between the FO of Cruciellipsis cuvillieri and the FO of Hayesites irregularis.

6.1.1.1. Subzone NC5E. This subzone is defined as the interval between the FOs of Flabellites oblongus and Hayesites irregularis.

6.1.1.1.1. Neszmély $\mathrm{N}-4$ borehole. In this borehole a siliciclastic sedimentary unit was penetrated between depths of 421 to 156 metres. In a sample from a depth of $351.0 \mathrm{~m}$, Micrantholithus obtusus, Micrantholithus hoschulzii, Nannoconus steinmanni, ? Braarudosphaera sp. and Assipetra terebrodentarius were found. The $284.0 \mathrm{~m}$ sample was barren, while the one from $219.0 \mathrm{~m}$ contained a very poor nannoflora, with some rare examples of species of Watznaueria inclusive of Watznaueria bayackii, plus M. hoschulzii, Braarudosphaera regularis, B. pseudobatilliformis, Diazomalithus lehmannii and Retecapsa surirella. The smear slide from $198.0 \mathrm{~m}$ contains a distinctly early Aptian nannoflora, with rare presence of the zonal index Hayesites irregularis, Helenea chiastia, $R$. surirella and $W$. bayackii. Only species of Watznaueria are very abundant, other forms are rare. The sample from $189.0 \mathrm{~m}$ contains a poor nannoflora in a moderate state of preservation with frequent nannoconids and species of Watznaueria. A smear slide from a depth of 169.7 m yielded Retecapsa crenulata, W. bayackii and $B$. regularis. In the upper levels of the borehole, at a depth of 

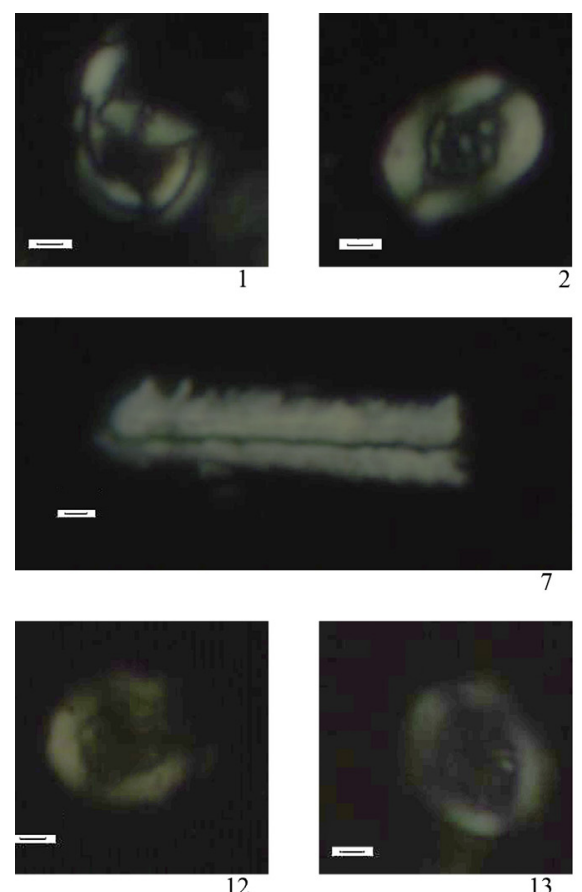

13

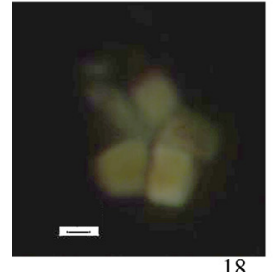

18

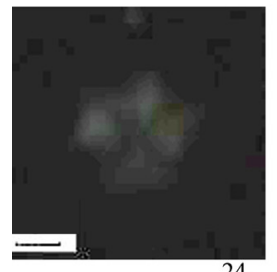

24

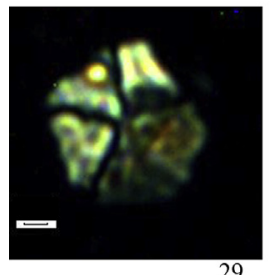

29
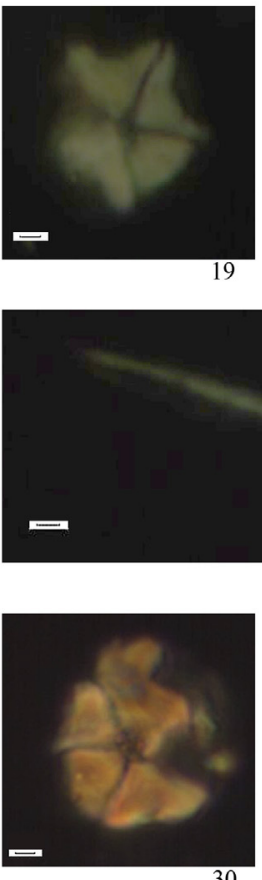
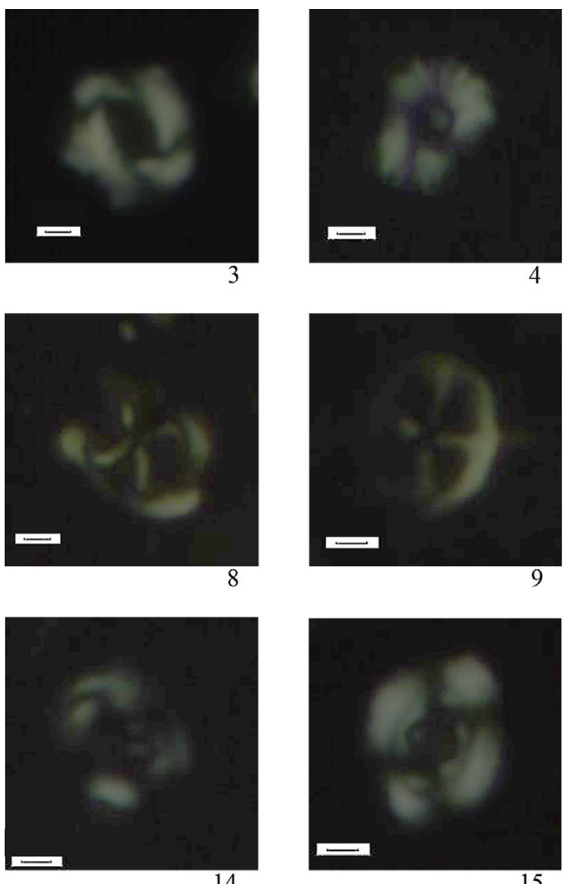

14
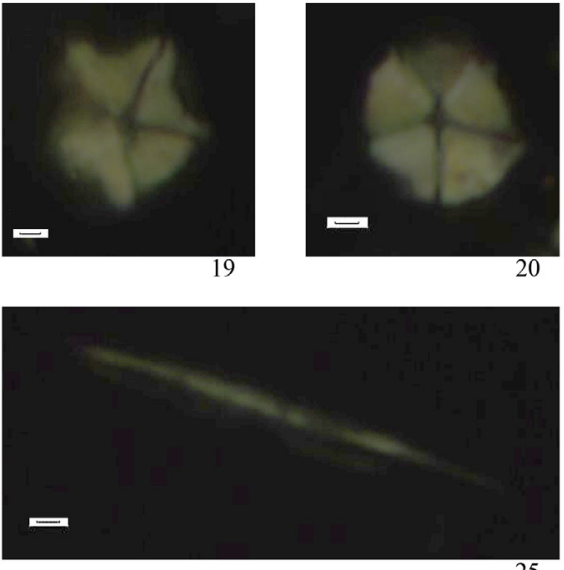

25
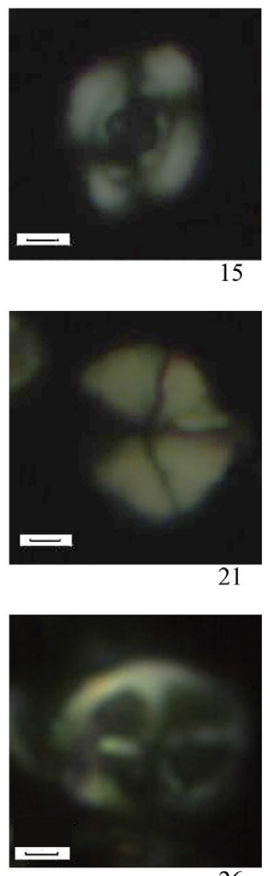

26

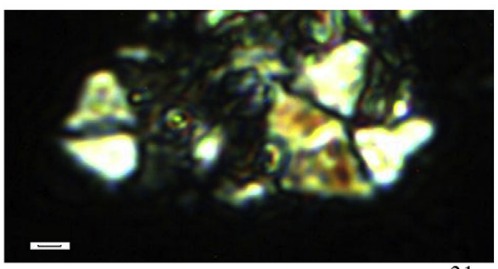

31
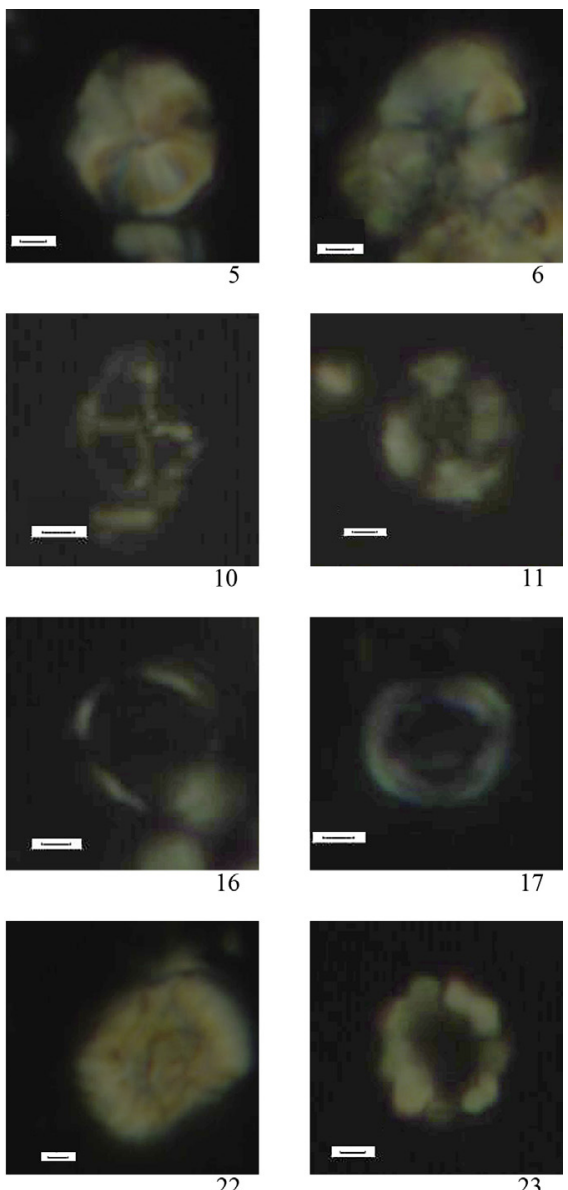

22
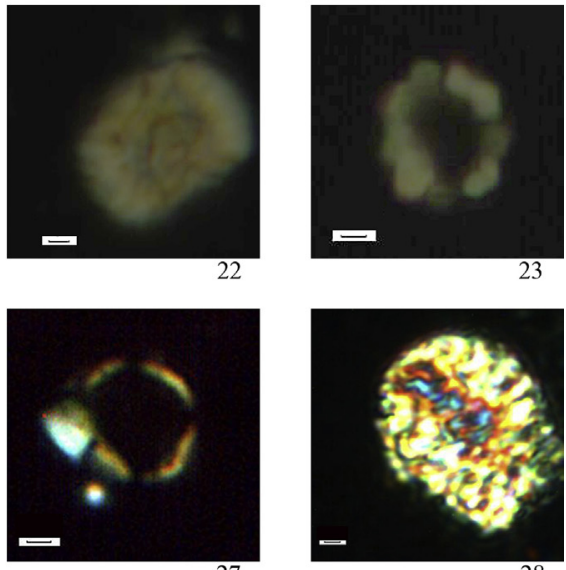

27
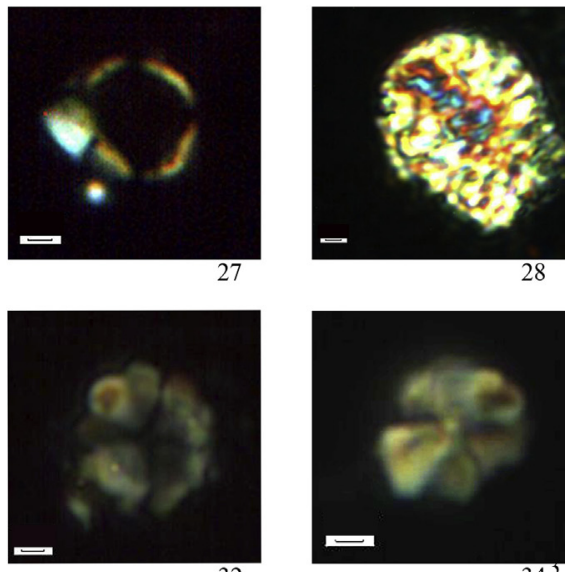

$34^{3}$

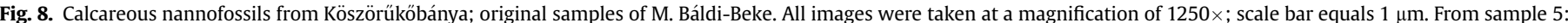

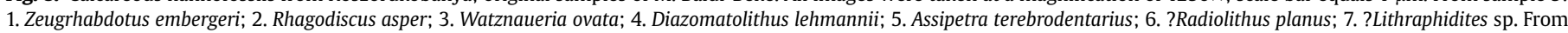

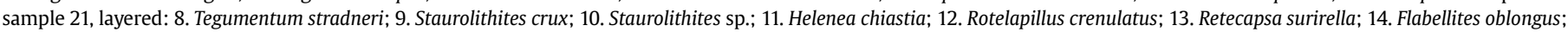

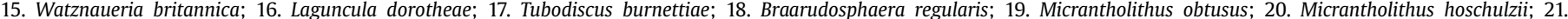

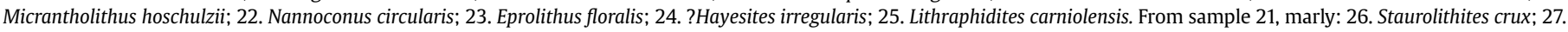

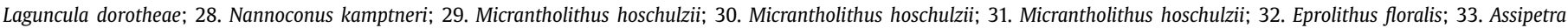
terebrodentarius.

$158.0 \mathrm{~m}$, the rock colour changes from grey to purplish grey. A smear slide prepared from this depth yielded a single Micrantholithus stellatus, and rare specimens of $R$. crenulata, A. terebrodentarius, Cyclogelosphaera margerellii, $B$. regularis, D. lehmannii and H. chiastia.
On the basis of ammonites, Horváth (1978a, b) placed the Barremian/Aptian boundary at $187 \mathrm{~m}$. A late Barremian-early Aptian ammonite fauna, with records of Toxancyloceras vandenhecki at $351 \mathrm{~m}$, Macroscaphites (Costidiscus) microcostatus and Barremites difficilis are at $187 \mathrm{~m}$. The ammonite fauna is now being revised, but 
a comprehensive age assignment is already available. At $158 \mathrm{~m}$ a specimen of Cheloniceras was found, at $156 \mathrm{~m}$ one of Deshayesites, both genera being exclusive to the lower Aptian. Full list of ammonite taxa identified by Horváth (1978a, b) with her original identifications (which is not have been revised yet) is listed in the Supplementary Appendix 1.

Császár (1995) reported that the upper 70.2 metres of the core (i.e., between 158 and $87.8 \mathrm{~m}$ ) were of late Aptian age. Unfortunately, this part of the core seems to be lost and because of the lack of fossil evidence we cannot be certain of this late Aptian date for this missing core interval.

In summary, we can place the Barremian/Aptian boundary (i.e., base of NC6) at the first certain occurrence of Braarudospera regularis and B. pseudobatilliformis at a depth of $219 \mathrm{~m}$. Although these are not zonal indexes, species of Braarudosphaera have no certain records below the Aptian (P. Bown, pers. comm., November, 2017). The FO of $H$. irregularis is at a depth of $198 \mathrm{~m}$ undoubtedly documents an Aptian time interval. Below $219.0 \mathrm{~m}$ zone NC5, above the presence of zone NC6 is assumed. In view of the absence of Eprolithus floralis, which would mark the base of zone NC7, the presence of this zone cannot be verified over the entire length of the core. This nannofossil zonation is in slight contradiction with the ammonite record, which placed the Barremian/Aptian boundary at $187 \mathrm{~m}$.
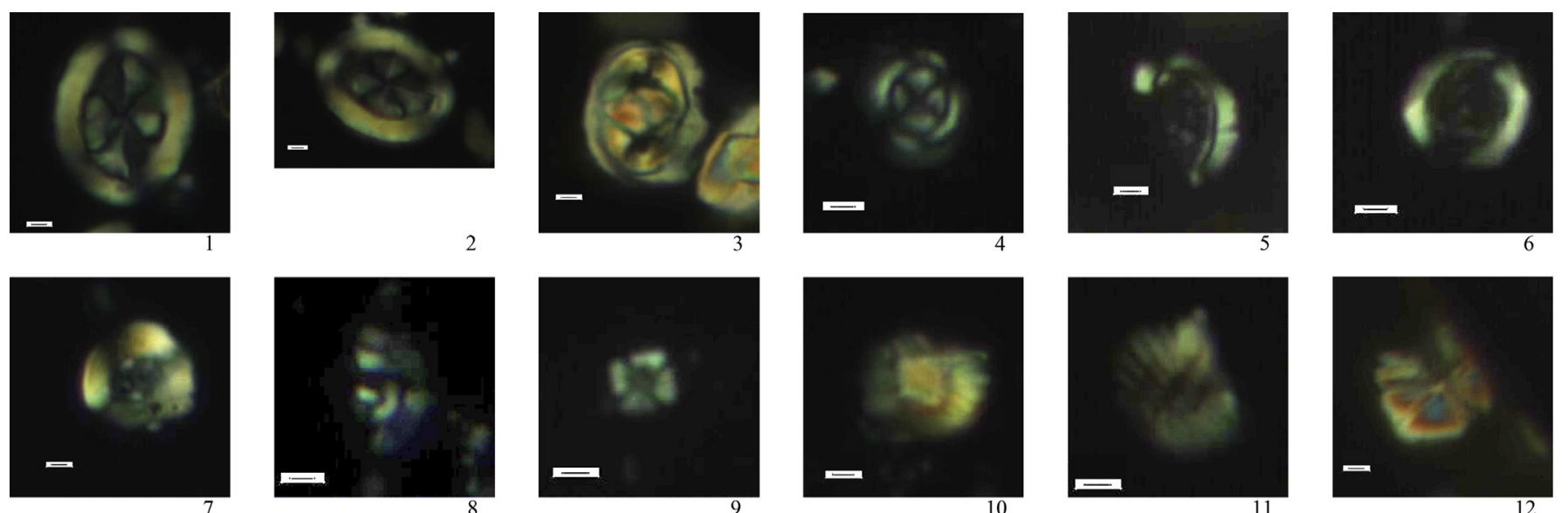

sample and poorly preserved, being mostly eroded and/or dissolved. Watznaueria is the sole fairly common taxon. Single specimens of Nannoconus steinmannii, Percivalia fenestrata and $H$. chiastia were noted. Nannoconus steinmannii has its last occurrence in the earliest Aptian (P. Bown, pers. comm., November, 2017). Watznaueria bayackii is also frequent. The presence of $N$. steinmannii and the absence of $H$. irregularis and Braarudosphaera lead us to conclude that the age is latest Barremian (subzone NC5E). Nannofossils from this outcrop are illustrated in Fig. 7.

6.1.1.1.3. Szél-hegy outcrops. Nannoflora of sample 2013-02-18 comprises very abundant Watznaueria and common nannoconids, $N$. kamptneri being commoner than $N$. steinmannii. One specimen of $H$. irregularis was also found, together with rare M. hoschulzii and M. obtusus. A form of Micrantholithus ?obtusus (Fig. 5/14) resembles the early Valanginian boreal zonal index form, Micrantholithus ? speetonensis. We conclude that the age of this sample is early Aptian (subzone NC6A), on the basis of the co-occurrence of the zonal index and $N$. steinmannii. The nannoflora of sample 2013-03-04 comprises one specimen of $F$. oblongus, rare $M$. obtusus, rare W. bayackii, Rhagodiscus amplus, Rhagodiscus infinitus and Rhagodiscus asper. Nannoconids are relatively frequent, with Nannoconus ?inornatus and $N$. kamptneri. The absence of $H$. irregularis, and the presence of $F$. oblongus and $N$. ? inornatus supports subzone NC5E
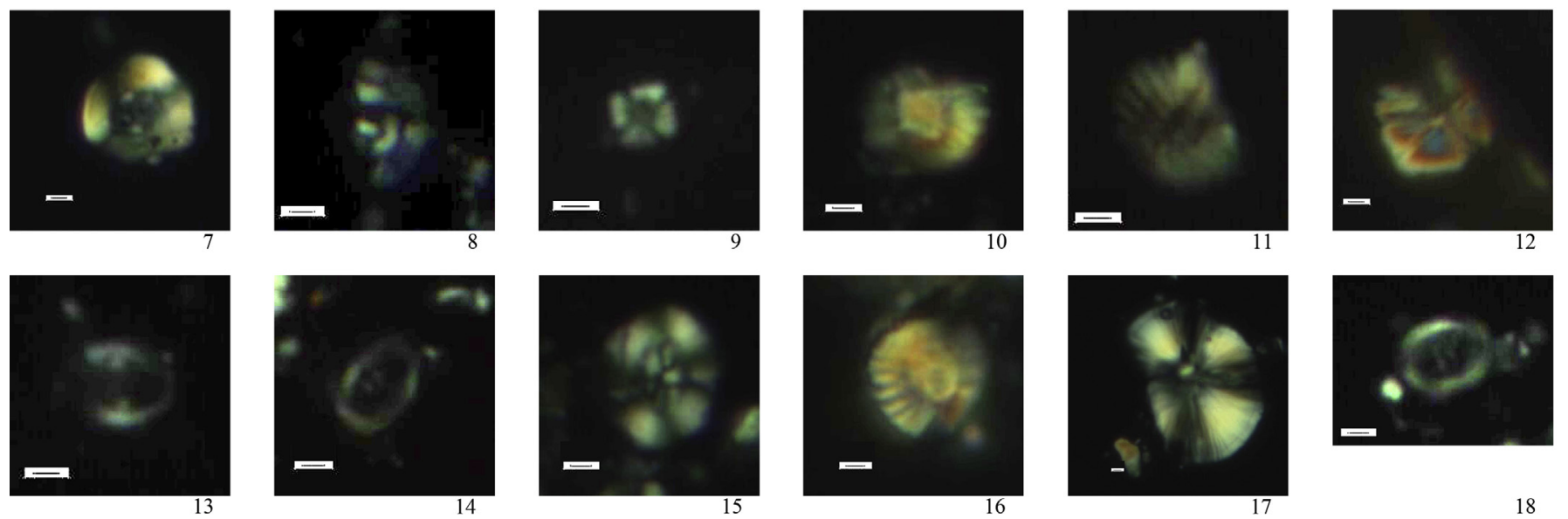

16
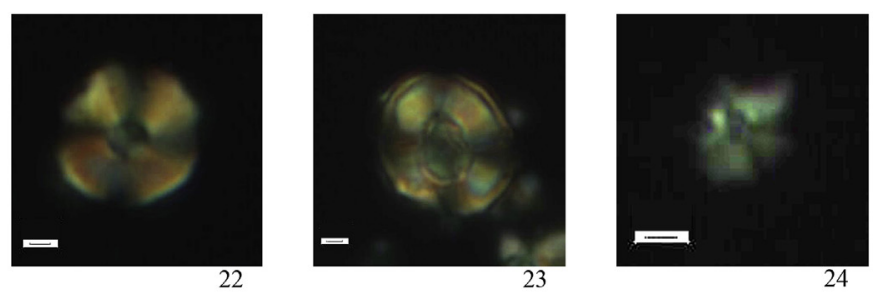

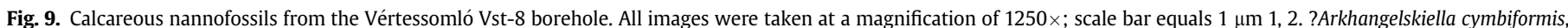

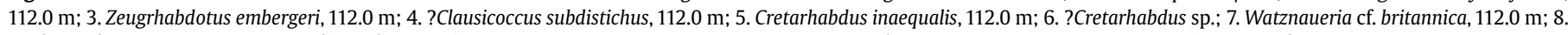

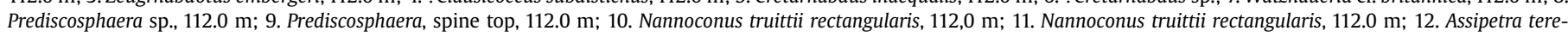

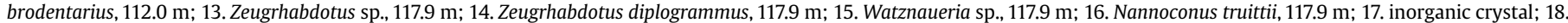

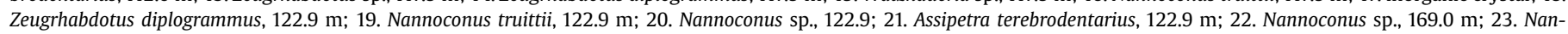
noconus sp., 169.0 m; 24. Hayesites irregularis, $169.0 \mathrm{~m}$. 


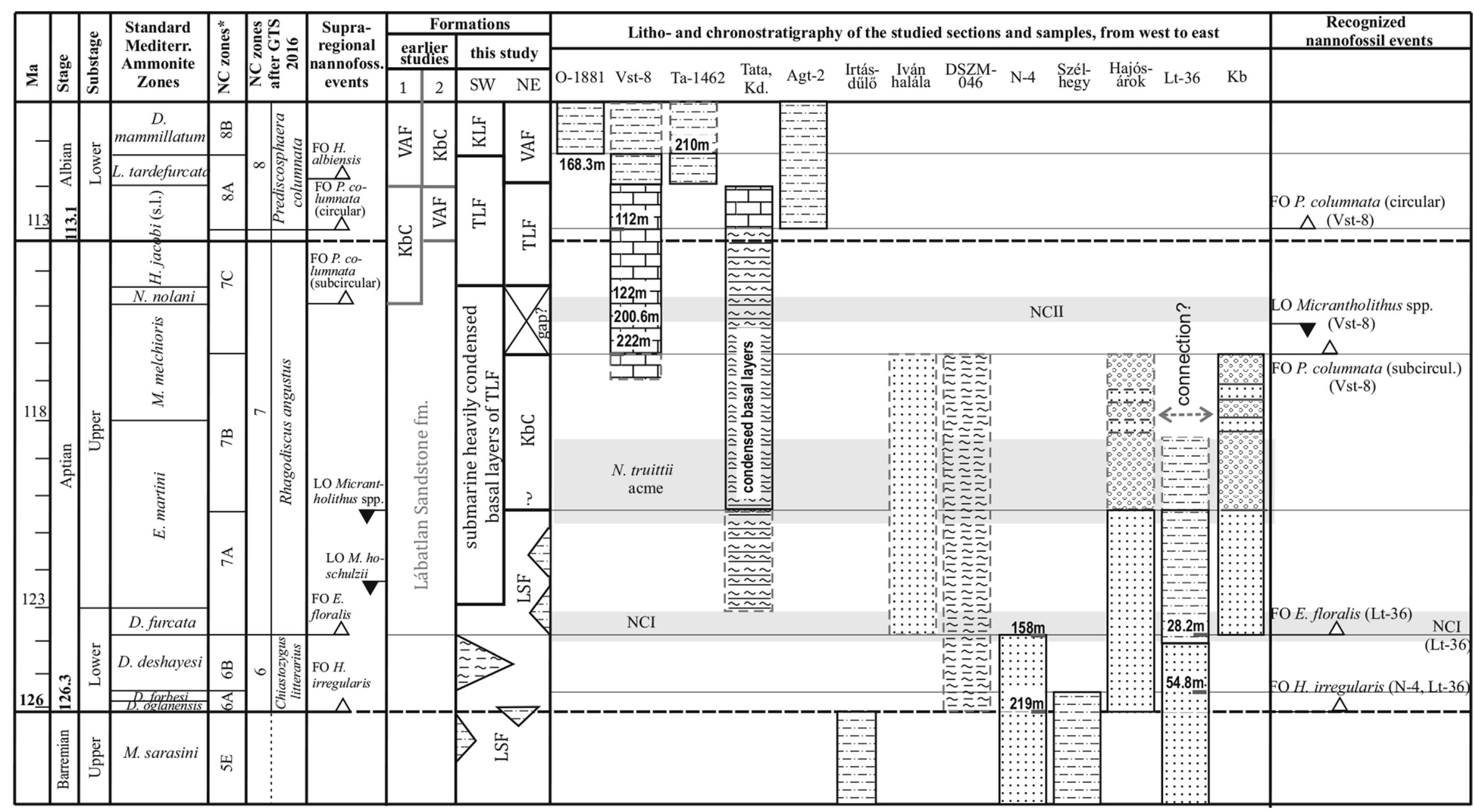

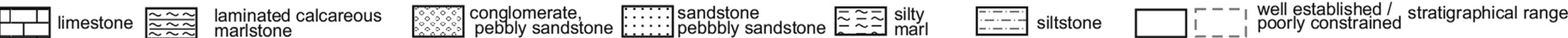

Fig. 10. Biostratigraphical results of the sites studied and revised age of clastic sequences of the northeastern Transdanubian Range. Note that investigated zones are scaled. From left to right: age and timing follows Ogg et al. (2016),

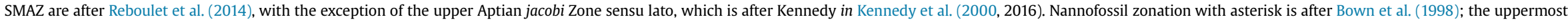
Aptian to lowermost Albian follows Bown in Kennedy et al. (2000, 2016). Nannofossil zonation and supraregional events are from Ogg et al. (2016), which is based on a "compilation of several sources", including Roth (1978), Bralower ât (1995) and Bown in Kennedy et al. (2000, 2016). Formations after (1): Császár (1995) and (2): Sztanó et al. (2018) are compared to the present study. KLF: Környe Limestone Formation; TLF: Tata Limestone Formation; LSF: Lábatlan

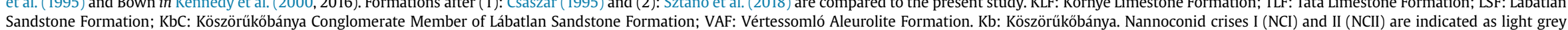
shaded areas, also as the Nannoconus truittii acme, on the basis of Erba (1994) and Herrle and Mutterlose (2003). 


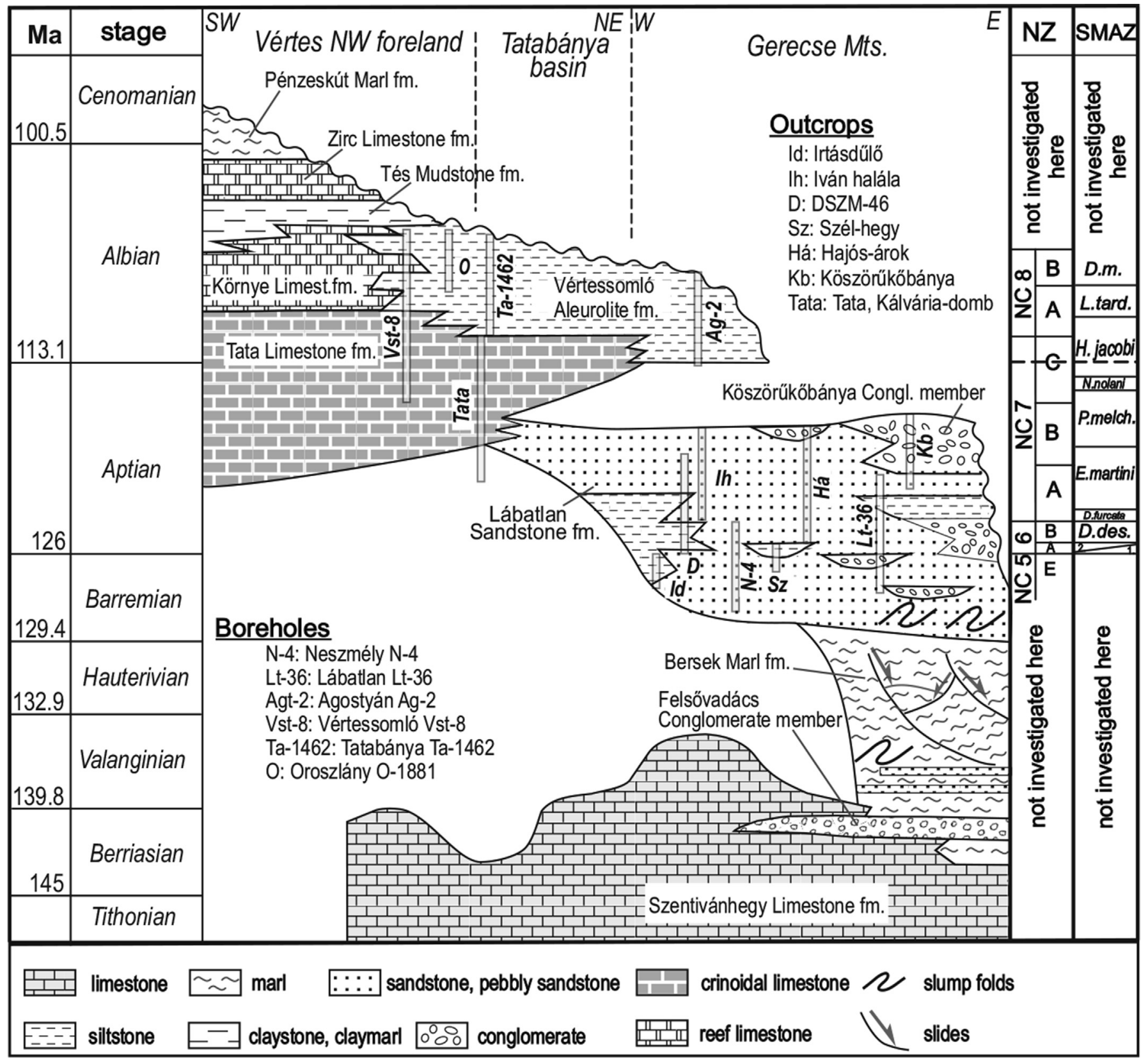

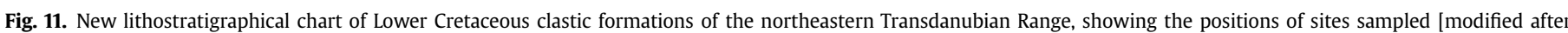

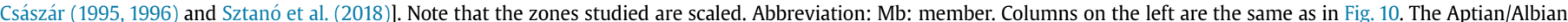
boundary is marked with a dashed line on the right. Two ammonite zones, of Deshayesites oglanensis (1) and Deshayesites forbesi (2), are both below the D. deshayesi Zone.

for this sample, which presumably makes it older than the previous sample from Szél-hegy. In summary, we can point out that samples from Szél-hegy are not of an Albian date, contrary to previous assumptions. (See Fig. 5).

\subsubsection{Chiastozygus litterarius Zone (NC6), lower Aptian}

This is an interval zone between the FOs of Hayesites irregularis and Eprolithus floralis.

It has been determined at Hajós-árok, which is discussed below under subzone NC7B.

6.1.2.1. Subzone NC6A. This subzone is defined as the interval between the FO of Hayesites irregularis and the LO of Conusphaera rothii. The presence of this subzone has been noted in the upper part of the core of the Neszmély N-4 borehole, Szél-hegy (both discussed above, under subzone NC5E), also at Hajós-árok and in the Lábatlan Lt-36 borehole (both discussed below under subzone NC7A).

6.1.2.2. Subzone NC6B. This interval is defined as the interval between the LO of Conusphaera rothii and the FO of Eprolithus floralis. This subzone could be proved in the Lábatlan Lt-36 borehole below $54.8 \mathrm{~m}$, on the basis of the FO of $H$. irregularis. Nannofossil taxa from this borehole are discussed below, under subzone NC7A.

\subsubsection{Rhagodiscus angustus Zone (NC7), upper Aptian}

This zone is defined as the interval between the FOs of Eprolithus floralis and circular Prediscosphaera columnata. 


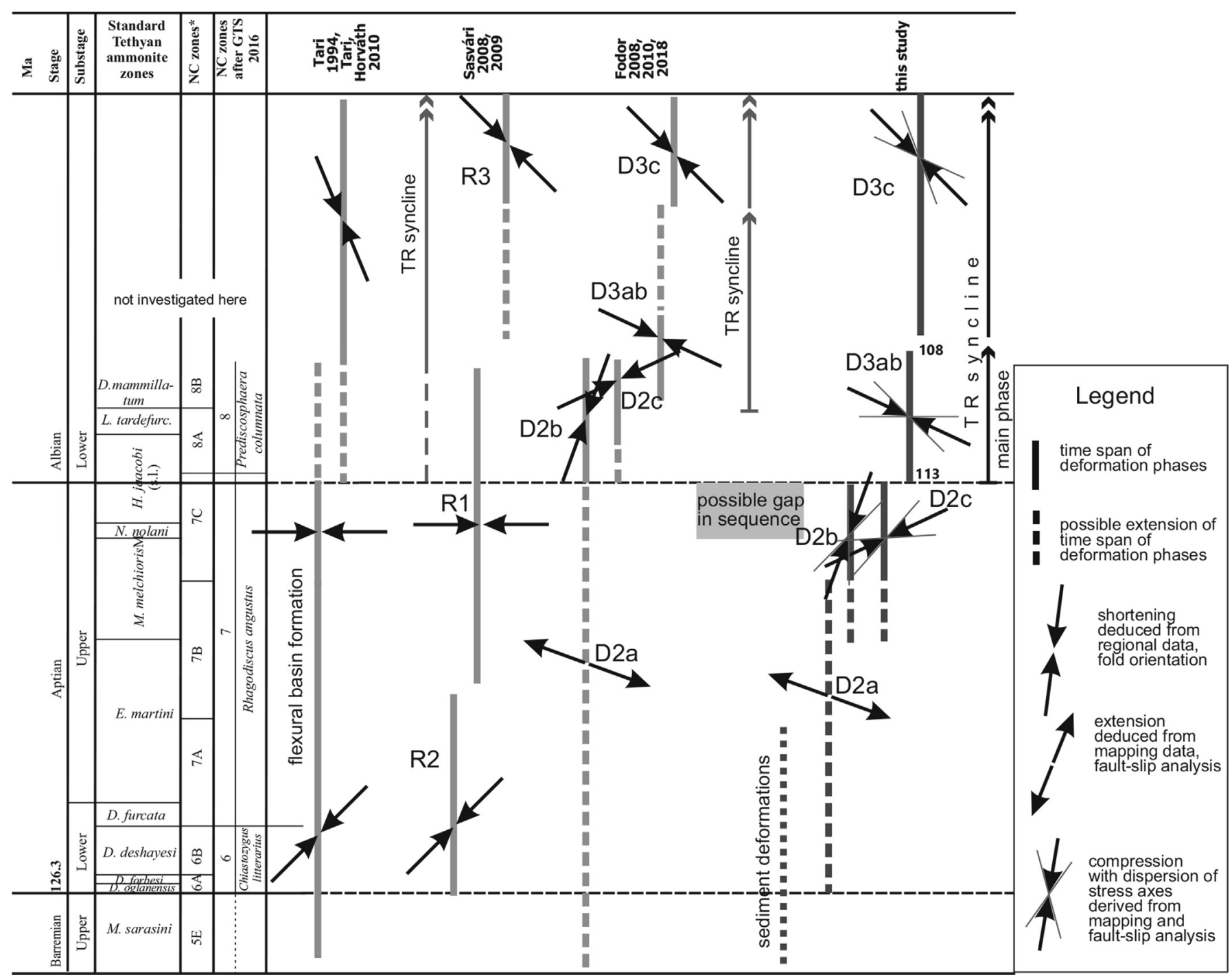

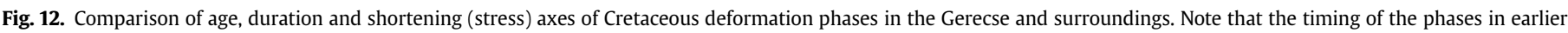

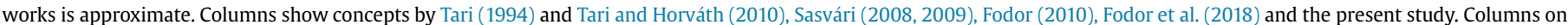
the left are the same as in Fig. 10 and 11.

6.1.3.1. DSZM-046 outcrop. Sample DSZM-046/1 contains a diverse nannoflora, with rare occurrences of $M$. hoschulzii, $R$. asper, $R$. angustus, Staurolithites sp., Zeugrhabdotus embergeri, Zeugrhabdotus noeliae and $W$. bayackii, co-occurring with frequent $W$. barnesiae and $B$. regularis. A single $H$. irregularis has also been documented, together with nannoconids: $N$. inornatus, $N$. circularis and Nannoconus sp. On the basis of the zonal index and frequent species of Braarudosphaera, as well as the decrease in numbers of Micrantholithus, we date this sample as zone NC6 or zone NC7.

Sample DSZM-046/2 has a diverse nannoflora consisting of frequent $W$. bayackii and $M$. hoschulzii, and rare occurrences of Eiffelithus striatus, Staurolithites sp., N. kamptneri, Nannoconus minutus and Nannoconus truittii. A single specimen of Zeugrhabdotus ?bicrescenticus has also been noted. Age-diagnostic forms are absent from this sample, but on the basis of the co-occurrence of $M$. hoschulzii and N. truittii, its age can be can be estimated as zone NC7. More precise subzonal identification was not possible due to a lack of subzonal indexes for both samples. In summary, we can remark that samples from outcrop DSZM-046 obviously are not Albian in age. (See Fig. 6)
6.1.3.2. Iván halála outcrop. The nannoflora from this locality contains a few specimens of Staurolithites crux, Owenia partitum, Owenia dispar, $R$. angustus, $R$. asper, H. chiastia, N. circularis, $B$. batilliformis, M. obtusus and E. floralis. A single specimen of Nannoconus bucheri has also been found, as well as a surprisingly young ?Owenia hillii. The FO of E. floralis marks the base of zone NC7. On the basis of the co-occurrence of M. obtusus, N. bucheri and $N$. circularis we place this sample in subzone NC7A. Species of Owenia indicate a slightly younger (subzone NC7B) age, which is why we cannot rule out this option either. In summary, we conclude that this sample is not of Albian age, but most likely can be placed in zones NC7A/B.

6.1.3.3. Subzone NC7A. This subzone is defined as the interval between the FO of Eprolithus floralis and the LO of Micrantholithus spp.

6.1.3.3.1. Lábatlan Lt-36 borehole. For a detailed nannofossil biostratigraphy of this core reference is made to Fogarasi (2001) and, in the framework of an integrated ammonite-nannofossil study, to Fözy et al. (2002).

Fogarasi examined 12 samples from between depths of 3.3 and 98 metres, and presented a range chart of the nannoflora 
recognised, summarising his opinion (in Főzy et al., 2002, Table 1, Fig. 1.) as follows, ' .... the age of the whole core can be placed between late Barremian to Aptian.'. In more detail, 'On the basis of our nannoplankton studies, we can identify forms of the NC6-NC7 zones. At $28.2 \mathrm{~m}$ the co-occurrence of $E$. floralis and $R$. angustus can be recognized, which marks the base of NC7A zone. ... Samples above this have not yielded biostratigraphically significant nannoflora, but more likely are younger in age.'

Nannoconids are missing totally between 54.8 and $28.2 \mathrm{~m}$, which can be interpreted as a nannoconid crisis more likely to be $\mathrm{NCI}$, considering the ammonite macrofauna that clearly represents a maximum earliest Aptian date (Fözy et al., 2002). In smear slides prepared from samples above $33.3 \mathrm{~m}$, the return of nannoconids and the presence of Micrantholithus is remarkable, which does not really support subzone NC7B or 7C ages, as previously suggested by Fogarasi. The negative correlation between nannoconids and A. infracretacea and A. terebrodentarius as documented by Herrle and Mutterlose (2003) could be observed in these samples. In addition to the nannoconid crisis $(\mathrm{NCI})$ around the boundary of subzones NC6B/7A, first pointed out by Erba (1994), Herrle and Mutterlose (2003) detected a younger nannoconid crisis around the boundary between subzones NC7B/7C, which they named nannoconid crisis II (NCII). They also correlated these crises with major carbonate platform-drowning events.

In the Lt-36 borehole, species of Micrantholithus occur also above the crisis. Young et al. (2014) placed the LO of M. hoschulzii in the late Aptian substage, as Erba (1996) had done at the top of subzone NC7C. Bralower et al. (1995) positioned the top of subzone NC7A on the basis of the LO of M. hoschulzii; the 2016 version of the GTS also shows the last Micrantholithus spp. to mark the top of subzone NC7A.

In summary, below $54.8 \mathrm{~m}$, the presence of subzone NC6A is documented on the basis of the FO of $\mathrm{H}$. irregularis, in accordance with ammonite data (Fözy et al., 2002). Between 54.8 and $28.2 \mathrm{~m}$, subzone NC6B has been determined. The zonal index $R$. angustus, together with $E$. floralis, appears at $28.2 \mathrm{~m}$, which may mark the base of subzone NC7A. In contrast to the original concept by Fogarasi, we have found no evidence for a younger (subzones NC7B or NC7C) age of the upper part of the Lt-36 core, not among nannofossil taxa, nor among ammonites.

6.1.3.3.2. Hajós-árok. Nannofossils of this locality were examined by Fogarasi (2001), but his original eight smear slides are lost. He described 42 species and assigned the nannoflora to subzones NC6A to NC7B, on the basis of the presence of $H$. irregularis, $E$. floralis and Braarudosphaera hockwoldensis. The NCI was also documented within this section on the basis of an acme of A. infracretacea and A. terebrodentarius, as well as an acme of N. truittii (Erba, 1994), (Herrle and Mutterlose, 2003) in the highest samples. Bodrogi (1999) also concluded that the age of the upper beds was late Aptian. The upper part of the section at Hajós-árok has several distinctive conglomerate levels which possibly could be coeval with the conglomerates at Köszörüköbánya, but needs further micropaleontologic investigations.

6.1.3.4. Subzone NC7B. This subzone is defined as the interval between the LO of Micrantholithus hoschulzii and the FO of Rhagodiscus achlyostaurion.

6.1.3.4.1. Köszörükőbánya. This locality exposes the youngest sedimentary unit of the entire Cretaceous clastic succession for which the most widely divergent age assignments have been suggested, varying between Aptian/Albian (Sztanó and Báldi-Beke, 1992) and Cenomanian (Félegyházy and Nagymarosi, 1991, 1992). None of these authors provided clear, identifiable images of ageindicative forms.
We re-examined the original smear slides of Báldi-Beke (see Sztanó and Báldi-Beke, 1992). Of the six smear slides, three were empty, but others contain an abundant nannoflora of moderate to good preservation. The nannoflora from this locality is described in more detail in view of the conflicting age interpretations of previous authors.

In sample ' 5 ' the following forms were found: $Z$. embergeri, $R h$. asper, W. ovata, D. lehmannii, A. terebrodentarius, ?Radiolithus planus and ?Lithraphidites sp. Sample '21. layered' yielded Tegumentum stradneri, Staurolithites crux, Staurolithites sp., H. chiastia, Rotelapillus crenulatus, $R$. surirella, F. oblongus, Watznaueria britannica, Laguncula dorotheae, Tubodiscus burnettiae, B. regularis, M. obtusus, M. hoschulzii, N. circularis, E. floralis, H. irregularis and Lithraphidites carniolensis. From sample '21. marly', we documented S. crux, $L$. dorotheae, N. kamptneri, M. hoschulzii, E. floralis and A. terebrodentarius., while Báldi-Beke mentioned but did not photograph (Sztanó and Báldi-Beke, 1992) from the same sample, Prediscosphaera sp. indet. Despite detailed search, we did not find any specimen that could be assigned to that genus.

Micrantholithus declined and disappeared across the late Barremian-early Aptian interval and Braarudosphaera appeared in the early Aptian according to P. Bown (pers. comm., 11.2017), which implies that these samples certainly cannot be of Albian age. The LO of M. hoschulzii marks the lower boundary of subzone NC7B (Bown et al., 1998). In contrast, Young et al. (2014) extended the range of this species to the top of the Aptian subzone NC7C, as Erba (1996) had done earlier. Herrle and Mutterlose (2003, fig. 5) reported the FO of Prediscosphaera sp. from the basal part of subzone NC7B, while, according to Bralower et al. $(1994,1995)$ and Bown et al. (1998), the FO of subcircular columnata is around the middle of subzone NC7C and close to the base of the Nolaniceras nolani SMAZ. Browning and Watkins (2008) published a biostratigraphical chart on some age-diagnostic taxa from the ODP Site $1049 \mathrm{C}$ and came to the same conclusion as far as Prediscosphaera is concerned as Bown (in Kennedy et al., 2000). According to Erba (1996), M. hoschulzii, $M$. floralis and the first species of Braarudosphaera (B. africana) can appear together without species of Prediscosphaera over the entire NC7 zone (of Rhagodiscus angustus) in the Tethyan realm.

Based on the above considerations, we here conclude that the age of the KbC samples falls with zone NC7 on the basis of the cooccurrence of $M$. hoschulzii, E. floralis and B. regularis. Most likely are subzone NC7A or, maximum, subzone 7B on account of the relative abundance of the genus Micrantholithus. We must strongly discard its possible extension into zone NC8 or higher on account of the complete lack of any zonal or subzonal index taxa, including subcircular or circular P. columnata. We cannot discard the option of resedimentation on the basis of the preservation. Based on geological mapping, and noted already by Fülöp (1958), similar conglomeratic layers are intercalated in the upper part of the Hajósárok sequence. This NC7A/B zonal age is in concordance with the one suggested by redeposited orbitolinids and other large foraminifera, which indicated a late Aptian (Schlagintweit, 1990) or 'younger than mid-Aptian age' (Görög, 1995) or 'clearly mid-Aptian age' (Görög, 1996). This time interval equates with the top of the Epicheloniceras martini to lower Parahoplites melchioris SMAZs.

6.1.3.5. Subzone NC7C. This subzone is defined as the interval between the FOs of Rhagodiscus achlyostaurion and Prediscosphaera columnata. This subzone cannot be determined on the basis of the material examined herein.

\subsubsection{Zone NC8, uppermost Aptian-lowermost Albian}

This zone represents the interval between the FOs of Prediscosphaera columnata and Axopodorhabdus albianus. 
6.1.4.1. Subzone NC8A. This subzone is defined as the interval between the FOs of Prediscosphaera columnata and Hayesites albiensis.

6.1.4.1.1. Tata, Kálvária-domb. At this locality, nannoconid data are contradictory. Fogarasi (2001, p. 58) prepared samples from the basal layers of the Tata Limestone Formation (TLF) and his assemblage suggests zone NC7, but without a more precise subzonal interpretation. In contrast, according to Báldi-Beke (in Császár, 1989), among other non-age-significant forms, several Prediscosphaera cretacea have been reported which suggested to her a latest Aptian and earliest Albian age (subzone NC8A).

Both nannofossil data are in absolute accordance with the work of Szives (1999, 2002) and Szives et al. (2007), who interpreted the ammonite fauna of the basal lenses to reflect a heavily condensed rock unit of intermittent marine sedimentation during the interval between the late early Aptian to earliest Albian, i.e., between the Epicheloniceras martini and Hypacanthoplites jacobi SMAZs. Representatives of age-significant genera for the lower Aptian, such as Deshayesites or Dufrenoyia, had not been found. Note that an extension of the $H$. jacobi Zone into the lowermost Albian was pointed out by Kennedy in Kennedy et al. (2000). Data on foraminifera by Sidó (1975) also support (sub)zones NC7C/NC8 for the basal TMF at Kálvária-domb.

Here we accept a NC7A to basal NC8A subzonal age for the basal layers of TLF; obviously, the overlying crinoidal limestone itself has to be younger. Note that this locality is named 'Tata' in Fig. 10.

6.1.4.1.2. Ta-1462 borehole. This borehole penetrated the deeply buried Vértessomló Aleurolite Formation. On the basis of dinocyst investigations, Leereveld (1992) dated this unit as late Aptian-early Albian. From a depth of 210 metres, there is a specimen of Brancoceras sp., which substantiates an early Albian date, most likely coeval with subzone NC8A (Szives et al., 2007, pl. 13, fig. 1).

6.1.4.2. Subzone NC8B. This subzone is defined as the interval between the FOs of Hayesites albiensis and Tranolithus orionatus.

6.1.4.2.1. Vértessomló Vst-8 borehole. Fogarasi (2001) reported several, non-age-significant taxa, in addition to the first specimen of $P$. columnata at $222 \mathrm{~m}$, the sole $M$. hoschulzii at $200.6 \mathrm{~m}$, and the only Rh. angustus at $168 \mathrm{~m}$. Several other P. columnata were described from $122 \mathrm{~m}$. There is no mention of any nannofossil record above $97.7 \mathrm{~m}$. On the basis on the FO of P. columnata he placed the base of NC8 at a depth of $222 \mathrm{~m}$.

The main problem is that Fogarasi (2001) did not mention if he had the subcircular or circular form of $P$. columnata, nor can this be determined from the photograph he provided, but this has strong chronostratigraphical consequences. According to the recent literature (Bown in Kennedy et al., 2000; Young et al., 2014), $M$. hoschulzii and P. columnata may co-occur just in the uppermost Aptian. The LO of M. hoschulzii is at a depth of $200.6 \mathrm{~m}$. Fogarasi reported $R$. angustus from $168 \mathrm{~m}$; $N$. truittii occurs at 222, 146 and $132 \mathrm{~m}$, which may reflect the acme (Erba, 1994), (Herrle and Mutterlose, 2003) if we accept the NC7B subzonal age for this depth interval. The first occurrence of $P$. columnata, without M. hoschulzii, is at $122 \mathrm{~m}$.

Fortunately, we were able to examine the nannoflora by obtaining 12 rock samples from the original core for smear slide preparation. The following forms were documented from $112.0 \mathrm{~m}$ : Z. embergeri, T. burnettiae, W. britannica, Axopodorhabdus dietzmanni, Prediscosphaera sp. circular form, a Prediscosphaera spine top, Nannoconus truittii rectangularis and A. terebrodentarius. The appearance of ?Arkhangelskiella cymbiformis (FO in the early Coniacian) and ?Clausicoccus subdistichus (FO in the Early Eocene) is very surprising, although Burnett (in Gale et al., 1996) also reported Arkhangelskiella? sp. from the Albian/Cenomanian boundary deposits of Mt. Risou, France. At a depth of $117.9 \mathrm{~m}$ we identified Zeugrhabdotus sp., Z. diplogrammus, $N$. truittii, H. chiastia and an inorganic crystal first misinterpreted as Haqius circumradiatus, while the sample from 122.9 m yielded $Z$. diplogrammus, $N$. truittii, Nannoconus sp., A. terebrodentarius and that from $169.0 \mathrm{~m}$ Nannoconus sp. and a single specimen of $H$. irregularis. (See Fig. 9)

Within the framework of these novel nannofossil data we can assume a NC7C/8A subzonal age, due to the complete absence of H. albiensis and T. orionatus. Here we place the AAB at $112.0 \mathrm{~m}$. If we accept data supplied by Fogarasi as mentioned above, the base of subzone NC7C can be placed at $222 \mathrm{~m}$, where the first Prediscosphaera sp. co-occurs with Micrantholithus sp. Foraminifera also show document an early Albian date (Görög, 1995; Szinger, 2008). Despite several citations in the literature, we did not find any papers on studies of dinocysts from Vst-8. In unpublished manuscripts, Leereveld (1992) recorded dinocysts of the Vértessomló Aleurolite Formation only from Ta-1462; these document a late Aptian-early Albian date.

6.1.4.2.2. Oroszlány $0-1881$ borehole. The $0-1881$ borehole represents a convincing example in which the age of the thick, finegrained unit can be determined without doubt as the Albian Vértessomló Aleurolite Formation. In conclusion, the presence of Douvilleiceras mammillatum at depths of 338.8 and $292 \mathrm{~m}$, together with the presence of Cleoniceras cf. cleon at $321.4 \mathrm{~m}$ suggest a late early Albian age (Douvilleiceras mammillatum SMAZ), which is almost matches the entire NC8B nannofossil zone.

6.1.4.2.3. Agostyán Agt-2 borehole. This core also penetrated the Albian Vértessomló Aleurolite Formation over an extensive (400 m) thickness. Here we summarise the former Geological Institute data base records, where Bodrogi (1985 in Császár, 1985, as an attachment, p. 1-7) subdivided the succession into three parts on the basis of foraminifera: 'Ticinella bejaouensis-Hedbergella gorbachikae, Hedbergella planispira-Hedbergella retroflexa and Ticinella primula interval zones can be distinguished along the core, younger or older Cretaceous sedimentary sequence has not been detected'. The first two foraminifer zones can be equated with the upper $H$. jacobi, the third one with the Leymeriella tardefurcata SMAZ. Sporomorphs (Juhász, 1983; Juhász, 1985 in; Császár, 1985) hinted at an early Albian date. On the basis of nannofossils, a slightly younger, middle Albian to possibly early Cenomanian age, was determined (Gaál, 1982 in; Császár, 1985). Unfortunately, neither rock, nor nannofossil sample were available from the core material. In summary, on the basis of the available fossil record of contemporaneous borehole data listed above, we accept an early Albian (zone NC8) age for the aleurolite.

\section{Discussion}

\subsection{Revised stratigraphy of the Gerecse clastic sequence}

Both nannofossils and ammonites demonstrate that the deposition of Lábatlan Sandstone Formation in the clastic sequence of the Gerecse Mountains continued until the early Aptian (N-4, Lt-36 borehole, Iván halála outcrop). On the other hand, the sandstones exposed in Hajós-árok outcrop are not younger than nannofossil subzone NC7B. This means that sandstone deposition possibly came to a halt during the middle late Aptian, as is shown on Fig. 10.

Already during the early Aptian, fine-grained sediments (siltstones) could intercalate into the sandstone-dominated formation (Szél-hegy, Irtásdülö). Outcrops suggest that the fine-grained units are the highest element in the vicinity, but a return of sandstone on a regional scale (e.g., projected from the Hajós-árok section) cannot be ruled out. The thickness of one fine-grained part can be judged from the DSZM-046 outcrop and nearby geophysical measurements (Zalai et al., 2015), where at least several dozens of metres of fine-grained rocks occur above the sandstone unit. At present the data are not precise enough to determine if these fine-grained parts 
refer to a single event, or represent several intercalations within the sandstone. However, when comparing the slightly different ages from Irtásdülö, DSZM-046, Szél-hegy and Lt-36, we would favour the latter interpretation, as here shown in Fig. 11.

These rocks of early Aptian age are clearly older than the early Albian Vértessomló Formation, to which they were previously assigned. Although the classification of these fine-grained intercalations was logical on the basis of lithology (Sztanó et al., 2018), a summary of the available biostratigraphical records, complemented with new data, appears to exclude the presence of Albian formations in the internal part of the Gerecse Mountains. However, the early Albian age of a thick sequence along the western margin of the Gerecse (e.g., Agt-2 borehole) and in the northwestern foreland of the Vértes Mountains (Vst-8 borehole) is still valid (Császár, 1995; present study, Figs. 10-11).

Our new biostratigraphical data suggest that the coarse-grained Köszörükőbánya Conglomerate $(\mathrm{KbC})$ unit is older than previously assumed by Sztanó and Báldi-Beke (1992), because there was no nannofossil evidence to as certain the previously published early Albian age. Instead, nannofossils indicate a maximum age of middle late Aptian (subzone NC7B) (see Figs. 8, 10, 11). This newly confirmed data is in accordance with the dinoflagellate and foraminiferal data for redeposited carbonate clast components of the unit, which also indicate a middle Aptian ('Gargasian') to early Albian date (Schlagintweit, 1990; Görög, 1995, 1996). The question is whether the coarser grain size of this unit, in comparison with the underlying ones, would represent a renewal of deformation, reorganisation of the drainage system in the hinterland of the gravity flows, or just an autocyclic change of sediment transport routes via migrating submarine canyons (Sztanó et al., 2018).

The new data allow us to link the KbC conglomerate and conglomerate intercalations that crop out in the upper part of the section of Hajós-árok, as both are of subzone NC7B age (Figs. 10, 11). Although suggested by Fülöp (1958), a formal attribution of the Hajós-árok conglomerates to the KbC Member is premature, and could be ruled out on the basis of absence or presence of an underlying siltstone unit in the Hajós-árok and Lt-36 borehole, respectively. However, the close temporal relationship of conglomerates and sandstones may indicate a coarsening-upward tendency, at least for the highest clastic units.

\subsection{Consequences for structural geological evolution}

Our new biostratigraphical data adapt the age of the $\mathrm{Kb}$ Conglomerate and (re)define the questionable ages of some outcrops. Our revision suggests a continuous sedimentation with the $\mathrm{KbC}$ as the uppermost unit; the youngest known deposition took place during the middle part of the late Aptian. In consequence, the hiatus (slow down of sedimentation rate), postulated within or just above the Lt-36 borehole (Sasvári, 2008), seems to loose its stratigraphical basis.

Thus, we conclude that the bulk of the first major Cretaceous deformation phase could have occurred after the deposition of the preserved clastic sequence, i.e., the Lábatlan Formation and $\mathrm{KbC}$. Theoretically, synsedimentary, contractional deformation during the late part of the clastic sequence, during the early to middle late Aptian (subzones NC7A, B) cannot be excluded (Sasvári, 2009), but this needs additional supporting data. The few structural data available mostly indicate sedimentary deformation (sliding, slump folding; Balkay, 1955; Fogarasi, 1995; Császár et al., 2012) and the presence of very minor extensional structures (D2a event in Fig. 12), instead of true shortening during the Barremian to early Aptian (Fodor et al., 2013; Fodor et al., 2018). While arguments for synsedimentary contraction are lacking, we suggest that the deformation front reached the Gerecse just after the deposition of presently known sedimentary units, during the latest Aptian. This deformation was an N-S to NE-SW shortening (NE-SW in Sasvári, 2008, 2009), which resulted in gentle folding (D2b subphase; see Fig. 12) (Fodor et al., 2018). The newly obtained age of the KbC brackets this D2b event to the late Aptian, probably during subzone NC7C, between 117 and 113 Ma (Fig. 12). Another subphase, D2c, including folds and strike-slip faults with a roughly ENE-WSW shortening, may also be of the same age. Clear temporal separation, and a relative chronology of the D2b and D2c subphases, have not yet been determined beyond doubt (Fodor et al., 2018), which is why we put them in the same time interval here (Fig. 12).

The late Aptian timing of the D2 phase is not in contradiction with, but lends more precision to, earlier views expressed by Tari (1994, 1995 in Hortváth et al. 1995) and Tari and Horváth (2010), who suggested Aptian thrusting with a southwesterly to westerly vergency. Late Aptian timing is also in agreement with the suggestion made by Pocsai and Csontos (2006) about a synsedimentary contractional Aptian deformation, although their conclusions were not supported by field structural data.

On the other hand, the geodynamic scenario is uniform in previous interpretations (Balla, 1981; Császár and Árgyelán, 1994; Mindszenty et al., 1994, 2001; Csontos et al., 2005; Sasvári, 2009; Fodor and Fózy, 2013); the deformation was related to Neotethyan obduction and additional contraction along the Adriatic margin.

In a wider Alpine-Dinaridic perspective, similar clastic sequences and deformations can be found (Fig. 1B, C). In the Northern Calcareous Alps, the Rossfeld Formation is lithologically similar to and has a comparable age as the Gerecse clastics (Fig. 1) (Decker et al., 1987; Árgyelán, 1996). Lower Cretaceous strata of the clastic Oštrc Formation occur in the Ivanščica Mountains (Fig. 1A, B) (Babić and Zupanič, 1973; Árgyelán, 1996; Babić et al., 2002; Lužar-Oberiter et al., 2012). Further west of the Ivanščica Mountains, in the Julian Alps Cretaceous, clastic sediments were described (Cousin, 1981; Goričan et al., 2012) (Fig. 1A), while further to the southwest in the Dinarides, Lower Cretaceous (Aptian) foreland sedimentary rocks constitute the Vranduk Formation (Mikes et al., 2008).

All these foreland basinal parts seem to surround the obducted Vardar ophiolite at its northwesterly termination; in palaeogeographical position they form a belt from the Rossfeld area to the Vranduk flysch basin (Fig. 1B). While obduction is Late Jurassic in age (Schmid et al., 2008) Early Cretaceous deformation imbricated the Adriatic (Neotethyan) passive margin (Csontos and Vörös, 2004). We have only limited knowledge of the amount of synsedimentary shortening of the preserved strata but it can be correlated to the D2a subphase in the Gerecse Mountains (Fig. 12). Postsedimentary imbrication and underthrusting is more pronounced and resulted in the westward migration of the thrust front (Fig. 1B, C). Although the age of this post-depositional deformation is poorly constrained, it is here tentatively connected to the D2b-c phase of the Gerecse. The D2 deformation of the Gerecse may also be similar to that observed in the Medvednica Mountains, a part of the passive Adriatic margin that crops out from below the ophiolite (Fig. 1B, C). Tomljenović et al. (2008) and Van Gelder et al. (2016) documented ductile deformation and low-grade metamorphism. Variable thermochronometric data indicate a time span between 135 and $110 \mathrm{Ma}$ for the deformation, possibly culminating around 113-110 Ma (Judik et al., 2006, 2008; Van Gelder et al., 2016). A tectonometamorphic event around $120 \mathrm{Ma}$ was reported from other parts of the Dinaridic nappe stack (see summary in Csontos and Vörös, 2004).

The newly suggested age for the D2 deformation would also imply constraints to the next D3 deformation phase of the Gerecse Mountains. The D3a-b subphases incorporate modest folds and strike-slip faults, while the compressional axes range from $\mathrm{E}-\mathrm{W}$ to 
NW-SE (Fig. 12). An early Albian age (113-108.5 Ma) can be put forward for these subphases (Fig. 12). This time frame would be the same as the age of the Vértessomló Formation; a future task would be to determine whether the deposition of this unit would have been syn-tectonic in origin or not. The continuation of the D3 phase, the largely post-folding D3c subphase could have extended for a longer period, from the middle Albian to the Coniacian ( $108-84 \mathrm{Ma})$, up to the deposition of the Upper Cretaceous ("Senonian") cover.

Although in the Gerecse Mountains the D3a-b subphases have smaller amplitude, they do represent a spatial continuation of major folding in the central and southern parts of the TR, generally referred to as the "formation of the TR syncline" (Fig. 1A) (Haas and Császár, 1987; Kiss and Fodor, 2003). For the age of these subphases Fodor $(1998,2010)$ emphasised the presence of an erosional surface which truncates folds and thrusts; these are covered by middle to upper Albian sedimentary rocks (Tés Claymarl and Zirc Limestone formations). This geometry was documented already by Mészáros (1968, 1979), Szabó (1985) and Albert (2000).

The D3a-b subphases of the present study may correspond to the second phase of Sasvári $(2008,2009)$ (R1 in Fig. 12). However, he still regarded this event as a continuation of the flexural basin evolution (Fig. 12) and put the onset of major Transdanubian folding only in the middle or late Albian (Fig. 12). Tari (1994) and Tari and Horváth (2010) formulated an idea that can be considered "intermediate" between ours and that of Sasvári (2008); they suggested that the flexural deformation of the Gerecse clastic basin continued during the early Albian but, overall, a NW-SE shortening (D3 phase) was already active in other parts of the TR (Fig. 12).

The geodynamic significance of the D3 phase is clearly established, while this indicates the onset of Eo-Alpine deformation (Austroalpine phase) in the TR. The difference between authors (Sasvári, 2008; Tari, 1994 and Tari and Horváth, 2010 vs Fodor et al., 2013; present study) is that the onset of the contraction is at the lower boundary or largely within the Albian, respectively (Fig. 12). An earliest Albian onset of Eoalpine contraction within the Eastern Alps is supported by data from the northern edge of the Northern Calcareous Alps. Wagreich $(2001,2003)$ pointed out that during the Albian to Cenomanian a long transpressional basin (TannheimLosenstein) existed which indicated the onset of "Austroalpine" transpressional deformation (Fig. 1A, C). In his concept this was related to the beginning of the Penninic subduction, although new models relate this deformation to intracontinental subduction (Handy et al., 2010; Stüwe and Schuster, 2010). The onset of this deformation (c. 114-112 Ma) shows a remarkable similarity to our own findings. This is younger than suggested for Austroalpine thrusting by Csontos and Vörös (2004).

The slightly younger, middle to late Albian deformation (D3c subphase of this study) can also be correlated with deformations in the Western Carpathians, where syn-tectonic sedimentation of basins in the Fatra-Klape domains started during the Albian (Plašienka, 1997, 2003) (Fig. 1A). In the Eastern Alps, contraction is well described both in the crystalline nappe units (Frank, 1987; Neubauer et al., 2000; Schmid et al., 2004) and in sedimentary rocks of the Northern Calcareous Alps (Linzer et al., 1995; Wagreich, 2001; Ortner, 2003). The major part of the deformation in the northern Eastern Alps is sealed by Upper Cretaceous (Turonian and younger) Gosau rocks of 90-80 Ma (Wagreich, 1993).

In palaeogeographical and tectonic reconstructions, the TR occupied a hanging wall position during the Eo-Alpine orogeny (Tari, 1994, 1995; Tari and Horváth, 2010), largely above the EoAlpine high-pressure belt (Schmid et al., 2008; Handy et al., 2010) (Fig. 1A-C) as supported by structural analysis) (Fodor et al. 2003). This reconstruction thus invokes a fundamental change of the TR from a position on the lower, subducting plate during the Early
Cretaceous (D2 phase of the present study), to the highest nappe during the Eolapine orogeny, from the Albian onwards. This change is due to a reorganisation of plates and oceanic domains. The opening of the Valais Ocean may trigger the Austroalpine orogenesis (Handy et al., 2010) (Alcapa; Fig. 1C). Because the TR became dominated by the Eoalpine orogenesis, the still ongoing subduction of the Neotethys lost its influence. If our chronostratigraphical determination is correct, the change from Neotethyan- to EoAlpine-dominated deformations occurred near the Aptian-Albian boundary, around $113 \mathrm{Ma}$ (Fig. 12). As pointed out by Wagreich (2001, 2003), the onset of "Austroalpine" transpressional deformation c. 114-112 myr ago is related to the beginning of the Penninic subduction and this deformation age shows a remarkable similarity to our own findings.

\section{Conclusions}

New and revised nannofossil data, in combination with ammonite records, lead us to offer more accurate constraints for the youngest members of the Cretaceous clastic sequences of the Gerecse Mountains, the northern Transdanubian Range (TR) in Hungary. The age of the Lábatlan Sandstone Formation (LSF) can be extended to early late Aptian, of a maximum up to nannozone NC7B. In its Aptian part, the sandstone-dominated sequence contains fine-grained siltstone or silty marl intercalations, which, in a lithology similar to, but in age distinct from the Vértessomló Aleurolite Formation. The Köszörükőbánya Conglomerate Member of LSF was deposited during the middle late Aptian, corresponding to subzones NC7A/B, i.e., definitely older than the previously suggested early Albian age. On the other hand, the early Albian age of the Vértessomló Aleurolite Formation has now been confirmed by nannofossils. The Tata Limestone Formation might have been laid down during the late Aptian to earliest Albian, although its highly condensed marly basal bed (preserved merely in two restricted areas) supposedly accumulated during a long time interval with an intermittent underwater sedimentation on the basis of integrated micropalaeontological and ammonite data. Deposition of the crinoidal Tata Limestone Formation can be interpreted as a source of bioclasts that were resedimented into the siliciclastic basin.

The new biostratigraphical framework permits a better timing of the major Cretaceous deformation phases of the Gerecse Mountains. Namely, the deformation related to the Neotethyan obduction and post-obductional shortening could have lasted up to the late Aptian (subzone NC7C) and could have incorporated largely post-sedimentary structures (folds, strike-slip faults) in the northeastern TR. The subsequent D3a-b subphases could be of early Albian age and incorporated folding and strike-slip faulting. Thus, the change from "Neotethyan" to the Eo-Alpine ("Austroalpine") deformation occurred around the Aptian/Albian boundary around $113 \mathrm{Ma}$, similar to the onset of deformation in the Eastern Alps. During these phases the TR changed its structural position from the lowermost to the uppermost, while the shortening direction changed from roughly NE-SW to $\sim \mathrm{NW}-\mathrm{SE}$.

\section{Acknowledgements}

This research was supported by the Hungarian National Research Found (NKFIH OTKA) 113013 and one of us (OSz) was supported by the Bolyai Research Grant of the Hungarian Academy of Sciences. Constructive comments and help in nannofossil identifications by Professor P. Bown (London) are greatly acknowledged. We are also grateful for the generous help and supportive teaching by Professor M. Báldi-Beke and for the assistance by A. Nyerges. Field assistance of numerous colleagues (among others, O. Sztanó, T. Budai, G. Császár and M. Palotai) and students of geology of the 


\section{Eötvös University (Budapest) contributed to understanding the structural and sedimentological aspects of the Gerecse Mountains. Corrections and constructive comments by Michał Krobicki (Kra- kow, Poland), an anonymous reviewer and the handling editor are highly appreciated.}

\section{References}

Albert, G., 2000. Folds of the Northern Bakony Mts (unpubl. MSc thesis). Eötvös University, Department of General and Historical Geology, Budapest, 89 pp. (in Hungarian).

Árgyelán, G.B., 1989. Detrital framework analysis of Lower Cretaceous turbidite sequence of Neszmély-4 borehole (W. Gerecse Mts., Hungary). Acta Mineralogica Petrographica 30, 127-136.

Árgyelán, G.B., 1996. Geochemical investigations of detrital chrome spinels as a tool to detect an ophiolitic source area (Gerecse Mountains, Hungary). Acta Geologica Hungarica 39, 341-368.

Babić, L., Zupanič, J., 1973. Uppermost Jurassic and Early Cretaceous deposits on Mt. Ivanščica (northern Croatia). Geologicheskij Vjesnik 26, 267-272 (in Croatian, with English summary).

Babić, L., Hochuli, P.A., Zupanič, J., 2002. The Jurassic ophiolitic mélange in the NE Dinarides: dating, internal structure and geotectonic implications. Eclogae Geologicae Helvetiae 95, 263-275.

Bada, G., Fodor, L., Székely, B., Timár, G., 1996. Tertiary brittle faulting and stress field evolution in the Gerecse Mts., N. Hungary. Tectonophysics 255, 269-289.

Bajnai, D., Pálfy, J., Martínez, M., Price, G., Nyerges, A., Főzy, I., 2017. Multi-proxy record of orbital-scale changes in climate and sedimentation during the Weissert Event in the Valanginian Bersek Marl Formation (Gerecs Mts., Hungary). Cretaceous Research 75, 45-60.

Balkay, B., 1955. Über einen Untertyp der Gesteinsbewegung. Földtani Közlöny 85 (2), 153-156.

Báldi-Beke, M., 1963. Coccolithophores of the Early Cretaceous Sedimentary Units of Hungary. Annual Report of the Hungarian Geological Survey of 1962, pp. 133-141 (in Hungarian).

Báldi-Beke, M., 1965. Hungarian nannoconids (Protozoa, Incertae sedis). Geologica Hungarica, Series Palaeontologia 30, 107-147 (in Hungarian).

Balla, Z., 1981. Geodynamic analysis of Cretaceous-Paleogene formations of Hungary. Általános Földtani Szemle 16, 89-182.

Bodrogi, I., 1985. Foraminifers of Agt-2 borehole. In: Császár, G. (Ed.), Report on the Cretaceous Succession of the Agt-2 borehole. Archives of the Hungarian Office for Mining and Geology (unpubl. manuscript, in Hungarian).

Bodrogi, I., 1992. Biostratigraphy and correlations of siliciclastic lower to middle Cretaceous formations of the Gerecse and Vértes foreland, on the basis of foraminifers. Archives of the Hungarian Office for Mining and Geology TEKT.057, 60 pp. (unpubl. manuscript, in Hungarian).

Bodrogi, I., 1999. A comprehensive study of the microflora and -fauna from accretional sequences of the Tethys during Tithonian to Albian times from the Gerecse Mts. and the Salzburg Calcareous Alps (unpubl. manuscript, in Hungarian).

Bodrogi, I., Fogarasi, A., 2002. New data on the stratigraphy of the Lower Cretaceous of the Gerecse Mts. (Hungary) and the Lackbach section (Austria). In: Wagreich, M. (Ed.), Aspects of Cretaceous Stratigraphy and Paleobiogeography. Stratigraphia Austriaca, Österreichische Akademie der Wissenschaften, Schriftenreihe der Erdwissenschaftlichen Kommission, 15, pp. 295-313.

Bown, P.R., Young, J., 1997. Mesozoic calcareous nannoplankton classification. Journal of Nannoplankton Research 19, 21-36.

Bown, P.R., Young, J., 1998. Techniques, pp. 16-28. In: Bown, P. (Ed.), Calcareous Nannofossil Biostratigraphy. Kluwer Academic Publishers, Dordrecht.

Bown, P.R., Rutledge, D., Crux, J., Gallagher, L., 1998. Lower Cretaceous. In: Bown, P. (Ed.), Calcareous Nannofossil Biostratigraphy. Kluwer Academic Publishers, Dordrecht, pp. 87-132.

Bralower, T.J., Arthur, M.A., Leckie, R.M., 1994. Timing and paleoceanography of oceanic dysoxia/anoxia in the Late Barremian to Early Aptian (Early Cretaceous). Palaios 9, 335-369.

Bralower, T.J., Leckie, R.M., Sliter, W., Thierstein, H., 1995. An integrated Cretaceous microfossil biostratigraphy. In: Berggren, W.A., Kent, D.V., Aubry, M.P., et al. (Eds.), Geochronology, Time Scales and Global Stratigraphic Correlation. Society of Economic Paleontologists and Mineralogists, Special Publication, 54, pp. 65-79.

Browning, E.L., Watkins, D.K., 2008. Elevated primary productivity of calcareous nannoplankton associated with ocean anoxic event $1 \mathrm{~b}$ during the Aptian/Albian transition (Early Cretaceous). Paleoceanography 23. PA2213.

Cousin, M., 1981. Les rapports Alpes-Dinarides. Les confins de l'Italie et de la Yougoslavie. Annales de la Societé géologique du Nord 5 (1-2), 1-521.

Császár, G., 1978. The Tés Clay Formation: a sketch of facies evaluation. Földtani Közlöny 108, 328-342.

Császár, G., 1985. Report on the Cretaceous succession of the Agt-2 borehole. Archives of the Hungarian Office for Mining and Geology (unpubl. manuscript, in Hungarian).

Császár, G., 1986. Middle Cretaceous formations of the Transdanubian Central Range: stratigraphy and connection with bauxite genesis. Geologica Hungarica, Series Geologica 23, 1-295.
Császár, G., 1989. Tata, Kálvária Hill, Nature Conservation Area. XXIst European Micropaleontological Colloquium Guidebook. Hungarian Geological Society, Budapest, pp. 208-220.

Császár, G., 1995. An overview of the Cretaceous research in the Gerecse Mountains and Vértes Foreland. Általános Földtani Szemle 27, 133-152.

Császár, G. (Ed.), 1996. Kréta. Magyarország litosztratigráfiai alapegységei. Hungarian Geological and Geophysical Survey, Budapest, 163 pp.

Császár, G., 2002. Urgon formations in Hungary. Geologica Hungarica, Series Geologica 25, 1-209.

Császár, G., Árgyelán, G.B., 1994. Stratigraphic and micromineralogic investigations on Cretaceous formations of the Gerecse Mountains, Hungary and their palaeogeographic implications. Cretaceous Research 15, 417-434.

Császár, G., Schlagintweit, F., Piros, O., Szinger, B., 2008. Is there any Dachstein Limestone fragment in the Felsövadács Breccia member? Földtani Közlöny 138 (1), 107-110.

Császár, G., Haas, J., Sztanó, O., Szinger, B., 2012. From Late Triassic passive to Early Cretaceous active continental margin of dominantly carbonate sediments in the Transdanubian Range, Western Tethys. Journal of Alpine Geology 54, 33-99.

Csontos, L., Vörös, A., 2004. Mesozoic plate tectonic reconstruction of the Carpathian region. Palaeogeography, Palaeoclimatology, Palaeoecology 210, 1-56.

Csontos, L., Sztanó, O., Pocsai, T., Bárány, M., Palotai, M., Wettstein, E., 2005. Late Jurassic-Early Cretaceous alpine deformation events in the light of redeposited sediments. Geolines 19, 29-31.

Czabalay, L., 1995. A study on the molluscan fauna in Cretaceous rocks in the Gerecse Mts. and the Vértes foreland, including its comparison with the environment. Általános Földtani Szemle 27, 109-131.

Decker, K., Faupl, P., Müller, A., 1987. Synorogenic sedimentation on the Northern Calcareous Alps during the Early Cretaceous, pp. 126-141. In: Flügel, H.W. Faupl, P. (Eds.), Geodynamics of the Eastern Alps. Franz Deuticke, Vienna.

Erba, E., 1994. Nannofossils and superplumes: the early Aptian "nannoconid crisis". Paleoceanography 9 (3), 483-501.

Erba, E., 1996. The Aptian stage. Bulletin de l'Institut royal des Sciences naturelles de Belgique 66, Supplement, 31-43.

Faupl, P., Wagreich, M., 1992. Cretaceous flysch and pelagic sequences of the Eastern Alps: correlations, heavy minerals, and paleogeographic implications. Cretaceous Research 13, 387-403.

Félegyházy, L., Nagymarosy, A., 1991. New data on the age of the Lower Cretaceous formations in the Gerecse Mountains (Hungary). Geologica Carpathica 42, $123-126$.

Félegyházy, L., Nagymarosy, A., 1992. Calcareous Nannoplankton stratigraphy of Lower Cretaceous formations in the Gerecse Mountains. Acta Geologica Hungarica 35, 251-262.

Fodor, L., 1998. Late Mesozoic and early Paleogene tectonics of the Transdanubian Range, p. 165. XIVth CBGA Congress. Geological Survey of Austria, Vienna, Austria.

Fodor, L., 2010. Mesozoic-Cenozoic Stress Fields and Fault Patterns in the Northwestern Part of the Pannonian Basin - Methodology and Structural Analysis (unpubl. DSc thesis). Hungarian Academy of Sciences, Budapest, 129 pp. (in Hungarian)

Fodor, L., Főzy, I., 2013. Late Middle Jurassic to earliest Cretaceous evolution of basin geometry in the Gerecse Mountains. In: Fözy, I. (Ed.), Late Jurassic-Early Cretaceous Fauna, Biostratigraphy, Facies and Deformation History of the Carbonate Formations in the GerEcse and Pilis Mountains. Geolitera Publishing House, Szeged, Hungary, pp. 117-135.

Fodor, L., Sztanó, O., Kövér, Sz, 2013. Mesozoic deformation of the northern Transdanubian Range (Gerecse and Vértes Mts.). Acta MinerologicaPetrographica, Field Guide Series 31, 2-34.

Fodor, L., Héja, G., Kövér, Sz, Csillag, G., Csicsek, Á.L., 2017. Cretaceous deformation of the south-eastern Transdanubian Range Unit, and the effect of inherited Triassic-Jurassic normal faults. Acta Mineralogica-Petrographica, Field Guide Series 32, 47-76.

Fodor, L., Kercsmár, Zs, Kövér, Sz, 2018. Structure and deformation phases of the Gerecse. In: Budai, T., Fodor, L., Sztanó, O., Kercsmár, Z.S., Császár, G., Csillag, G., Gál, N., Kele, S., Kiszely, M., Selmeczi, I., Babinszki, E., Thamó-Bozsó, E., Lantos, Z. (Eds.), Geology of the Gerecse Mountains. Explanatory book to the geological map of the Gerecse Mountains (1:50 000)]. Mining and Geological Survey of Hungary, Budapest, 169-209, 370-386.

Fogarasi, A., 1995. Sedimentation on tectonically controlled submarine slopes of Cretaceous age, Gerecse Mts., Hungary - working hypothesis. Altalános Földtani Szemle 27, 15-41.

Fogarasi, A., 2001. Stratigraphy of Calcareous Nannoplankton of the Lower Cretaceous of the Transdanubian Range (unpubl PhD thesis). Eötvös Loránd University, Department of General and Historical Geology, Budapest, 95 pp. (in Hungarian).

Fözy, I., 1995. Lower Cretaceous ammonite biostratigraphy of the Bersek Hill (Gerecse Mts., Hungary). Általános Földtani Szemle 27, 7-14.

Fözy, I., Fogarasi, A., 2002. The Lower Cretaceous biostratigraphy of the Bersek Hill (Gerecse Mts, Transdanubian Range) on the basis of the ammonites and nannofossils. Földtani Közlöny 132 (3-4), 293-324.

Főzy, I., Janssen, N., 2009. Integrated Lower Cretaceous biostratigraphy of the Bersek Quarry, Gerecse Mountains, Transdanubian Range, Hungary. Cretaceous Research 30, 75-90.

Fözy, I., Fogarasi, A., Szives, O., 2002. Integrated ammonite and calcareous nannofossil biostratigraphy of the Borehole Lábatlan-36 (Upper Barremian-Aptian, Transdanubian Range, Hungary). Földtani Közlöny 132 (1), 45-57. 
Főzy, I., Fodor, L., Janssen, N., Meléndez, G., Price, G., Riegraf, W., Scherzinger, A., Szente, I., Szinger, B., Szives, O., Vörös, A., 2013. Late Jurassic-Early Cretaceous Fauna, Biostratigraphy, Facies and Deformation History of the Carbonate Formations in the Gerecse and Pilis Mountains. Geolitera Publishing House Szeged, Hungary, pp. 1-421.

Frank, W., 1987. Evolution of the Austroalpine elements in the Cretaceous, pp. 379-406. In: Flügel, H.W., Faupl, P. (Eds.), Geodynamics of the Eastern Alps. Deuticke, Vienna.

Frau, C., Bulot, L.G., Delanoy, G., Moreno-Bedmar, J.A., Masse, J.-P., Tendil, A.J.-B. Lanteaume, C., 2017. The Aptian GSSP candidate at Gorgo a Cerbara (Central Italy): an alternative interpretation of the bio-, litho- and chemostratigraphic markers. Newsletters on Stratigraphy. https://doi.org/10.1127/nos/2017/0422.

Fülöp, J., 1958. Cretaceous deposits of the Gerecse Mountains (in Hungarian). Geologica Hungarica, Series Geologica 11, 1-124.

Fülöp, J., 1964. Lower Cretaceous (Berriasian-Aptian) sedimentary rocks of the Bakony Mts, Geologica Hungarica, Series Geologica 13, 1-225 (in Hungarian).

Fülöp, J., 1976. The Mesozoic basement horst blocks of Tata. Geologica Hungarica, Series Geologica 16, 1-121.

Fülöp, J., 1997. Cretaceous deposits of the Vértes-foreland in the neighbourhood of Pusztavám, pp. 47-122. In: Haas, J. (Ed.), Fülöp József Memorial Book Akadémiai Kiadó, Budapest.

Gaál, M., 1982. Nannoplankton research of the Cretaceous part of Agostyán Agt-2 borehole. Komló. In: Császár, G. (Ed.), 1985. Report on the Cretaceous Succession of the Agt-2 Borehole. Archives of the Hungarian Office for Mining and Geology (unpubl. manuscript, in Hungarian).

Gale, A.S., Kennedy, W.J., Burnett, J.A., Caron, M., Kidd, B.E., 1996. The Late Albian to Early Cenomanian succession at Mont Risou near Rosans (Drôme, SE France): An integrated study (ammonites, inoceramids, planktonic foraminifera, nannofossils, oxygen and carbon isotopes). Cretaceous Research 17, 515-606.

Goričan, Š., Košir, A., Rožič, B., Šmuc, A., Gale, L., Kukoč, D., Celarc, B., Črne, A.E. Kolar-Jurkovšek, T., Placer, L., Skaberne, D., 2012. Mesozoic deep-water basins of eastern Southern Alps (NW Slovenia). Field Trip Guide, 29th IAS Meeting of Sedimentology, Schladming, Austria. Journal of Alpine Geology 54, 101-143.

Görög, Á., 1995. Cretaceous larger foraminifera and their stratigraphy from the Vértes foreland and the Gerecse Mts (Hungary). Általános Földtani Szemle 27, 85-94.

Görög, Á., 1996. Cretaceous Orbitolinids of Hungary: Stratigraphic and Paleoecologic Interpretations (Unpublished $\mathrm{PhD}$ thesis, in Hungarian). ELTE University Budapest, 329 pp.

Haas, J., Császár, G., 1987. Cretaceous of Hungary. Paleogeographic implication. Rendiconti della Società Geologica Italiana 9 (2), 203-208.

Haas, J., Hámor, G., 2001. Geological garden in the neighbourhood of Budapest. Episodes 24 (4), 257-261.

Hancock, J.M., 2001. A proposal for a new position for the Aptian/Albian boundary. Cretaceous Research 22, 677-683.

Handy, M.R., Schmid, S.M., Bousquet, R., Kissling, E., Bernoulli, D., 2010. Reconciling platetectonic reconstructions of Alpine Tethys with the geological-geophysical record of spreading and subduction in the Alps. Earth-Science Reviews 102,121-158.

Hantken, M., 1868. Geology of the Lábatlan area. Magyarhoni Földtani Társulat Munkálatai 4, 48-56 (in Hungarian).

Hart, M.B., Amédro, F. Owen, H.G., 1996. The Albian stage and substage boundaries. Bulletin de l'Institut royal des Sciences naturelles de Belgique 66, Supplement, 45-56.

Herrle, J.O., Mutterlose, J., 2003. Calcareous nannofossils from the Aptian-Lower Albian of southeast France: palaeoecological and biostratigraphical implications. Cretaceous Research 24, 1-22.

Horváth, A., 1978a. Report on the macrofauna of the Neszmély N-4 borehole. Archives of the Hungarian Office for Mining and Geology (unpubl. report), pp. 1-4 (in Hungarian).

Horváth, A., 1978b. Additions to the macrofauna of the Neszmély N-4 borehole. Archives of the Hungarian Office for Mining and Geology (unpubl. report), 1 pp. (in Hungarian).

Judik, K., Balogh, K., Tibljaš, D., Árkai, P., 2006. New age data on the lowtemperature regional metamorphism of Mt. Medvednica (Croatia). Acta Geologica Hungarica 49 (3), 207-221.

Judik, K., Rantitsch, G., Rainer, T.M., Árkai, P., Tomljenović, B., 2008. Alpine metamorphism of organic matter in metasedimentary rocks from Mt. Medvednica (Croatia). Swiss Journal of Geosciences 101 (3), 605-616.

Juhász, M., 1983. Palynostratigraphic zonation of the Transdanubian Middle Cretaceous. Acta Geologica Hungarica 26, 41-68.

Juhász, M., 1985. Palynology of Agt-2 borehole. In: Császár, G. (Ed.), Report on the Cretaceous Succession of the Agt-2 borehole. Archives of the Hungarian Office for Mining and Geology (unpubl. manuscript) (in Hungarian).

Kázmér, M., 1987. A Lower Cretaceous submarine fan sequence in the Gerecse Mts. Hungary. Annales Universitatis Scientiarium Budapestinensis de Lorando Eötvös Nominatae, Sectio Geologica 27, 101-116.

Kázmér, M., 1988. Lower Cretaceous facies zones in Bakony unit of Hungary. Annales Universitatis Scientiarium Budapetinensis de Rolando Eötvös Nominatae, Sectio Gcologica 28, 161-168.

Kennedy, W.J., Gale, A.S., Bown, P.R., Caron, M., Davey, R.J., Gröcke, D., Wray, D.S., 2000. Integrated stratigraphy across the Aptian-Albian boundary in the Marnes Bleues, at the Col de Pré-Guittard, Arnayon (Drôme), and at Tartonne (Alpes-deHaute-Provence), France: a candidate global boundary stratotype section and boundary point for the base of the Albian Stage. Cretaceous Research 21, $591-720$.
Kennedy, W.J., Gale, A.S., Huber, B., Petrizzo, M.R., Bown, P., Barchetta, A., Jenkyns, H.C., 2014. Integrated stratigraphy across the Aptian/Albian boundary at Col de Pre-Guittard (southeast France): a candidate Global Boundary Stratotype Section. Cretaceous Research 51, 248-259.

Kennedy, W.J., Gale, A.S., Huber, B.T., Petrizzo, M.R., Bown, P., Jenkyns, H.C., 2017. The Global Boundary Stratotype Section and Point (GSSP) for the base of the Albian Stage, of the Cretaceous, the Col de Pré-Guittard section, Arnayon, Drôme, France. Episodes 40 (3), 177-188.

Kiss, A., Fodor, L., 2003. Brittle structures of the Bakony Mts., western Hungary. Constraints from paleostress analysis and local structural mapping. Annales Universitatis Scientiarum Budapestinensis de Rolando Eötvös Nominatae 35, 92-93.

Leereveld, H., 1992. Dinoflagellate cysts of well Vértessomló Vst-8. Archives of the Hungarian Geological and Geophysical Survey (unpubl. report).

Linzer, H.G., Ratschbacher, L., Frisch, W., 1995. Transpressional collision structures in the upper crust: the fold-thrust belt of the Northern Calcareous Alps. Tectonophysics 242, 41-61.

Lužar-Oberiter, B., Mikes, T., Dunkl, I., Babić, L., von Eynatten, H., 2012. Provenance of Cretaceous synorogenic sediments from the NW Dinarides (Croatia). Swiss Journal of Geosciences 105 (3), 377-399.

Mahanipour, A., Mutterlose, J., Kani, K.L., Adabi, M.H., 2011. Paleoecology and biostratigraphy of early Cretaceous (Aptian) calcareous nannofossils and the $\delta^{13} \mathrm{C}_{\text {carb }}$ isotope record from NE Iran. Cretaceous Research 32, 331-356.

Mészáros, J., 1968. Geological Investigation of the Surroundings of VároslődHerend-Szentgál-Úrkút. Annual Report from Year 1966. Geological Institute of Hungary, Budapest, pp. 53-72.

Mészáros, J., 1979. Explanatory Booklet to the Geological Map Series of the Bakony Mts., 1:20,000, Sheet Ajka. Geological Institute of Hungary, Budapest, 61 pp.

Mikes, T., Christ, D., Petri, R., Dunkl, I., Frei, D., Báldi-Beke, M., Reitner, J., Wemmer, K., Hrvatović, H., von Eynattten, H., 2008. Provenance of the Bosnian Flysch. Swiss Journal of Geosciences 101 (Supplement 1), 31-54.

Mindszenty, A., Knauer, J., Mátéfi-Stefler, M., 1994. Superimposed paleokarst phenomena in the Halimba basin (South Bakony, Hungary) - the anomality of a multiple regional unconformity. Abstracts IAS 15th Regional Meeting, Ischia, Italy, p. 285.

Mindszenty, A., Csoma, A., Török, Á., Hips, K., Hertelendi, E., 2001. Rudistid limestones, bauxites, paleokarst and geodynamics. The case of the Cretaceous of the Transdanubian Range. Földtani Közlöny 131 (1-2), 107-152.

Neubauer, F., Genser, J., Handler, R., 2000. The Eastern Alps: result of a two-stage collision process. Mitteilungen der Österreichischen Geologischen Gesellschaft 92, 117-134.

Ogg, J.G., Ogg, G.M., Gradstein, F.M., 2016. A Concise Geologic Time Scale. Elsevier, Amsterdam, 234 pp.

Ortner, H., 2003. Cretaceous thrusting in the western part of the Northern Calcareous Alps (Austria) - evidences from synorogenic sedimentation and structural data. Mitteilungen der Österreichischen Geologischen Gesellschaft 94, 63-77.

Owen, H.G., 2002. The base of the Albian Stage; comments on recent proposals. Cretaceous Research 23 (1), 1-13.

Petrizzo, M.R., Huber, B.T., Gale, A.S., Barchetta, A., Jenkyns, H.C., 2012. Abrupt planktic foraminiferal turnover across the Niveau Kilian at Col de Pré-Guittard (Vocontian Basin, southeast France): new criteria for defining the Aptian/Albian boundary. Newsletters on Stratigraphy 45 (1), 55-74.

Plašienka, D., 1997. Cretaceous tectonochronology of the Central Western Carpathians (Slovakia). Geologica Carpathica 48, 99-111.

Plašienka, D., 2003. Development of basement-involved fold and thrust structures exemplified by the Tatric-Fatric-Veporic nappe system of the Western Carpathians (Slovakia). Geodinamica Acta 16, 21-38.

Pocsai, T., Csontos, L., 2006. Late Aptian-Early Albian syn-tectonic facies-pattern of the Tata Limestone Formation (Transdanubian Range, Hungary). Geologica Carpathica 57 (1), 15-27.

Reboulet, S., Szives, O., Aguirre-Urreta, M.B., Barragán, R., Company, M., Idakieva, V., Ivanov, M., Kakabadze, M., Moreno-Bedmar, J.A., Sandoval, J., Baraboshkin, E.J., Çaglar, M.K., Főzy, I., González-Arreola, C., Kenjo, S., Lukeneder, A., Raisossadat, S.N., Rawson, P.F., Tavera, J., 2014. Report on the 5th International Meeting of the IUGS Lower Cretaceous Ammonite Working Group, the Kilian Group (Ankara, Turkey, 31st August 2013). Cretaceous Research 50, 127-137.

Reboulet, S., Szives, O., Aguirre-Urreta, B., Barragán, R., Company, M., Frau, C., Kakabadze, M., Klein, J., Moreno-Bedmar, J., Lukeneder, A., Pictet, A., Ploch, I., Raissosadat, S., Vašíček, Z., Baraboshkin, E., Mitta, V., 2018. Report on the 6th International Meeting of the IUGS Lower Cretaceous Ammonite Working Group, the Kilian Group (Vienna, Austria, 20th August 2017). Cretaceous Research 91, 100-110. https://doi.org/10.1016/j.cretres.2018.05.008.

Roth, P.H., 1978. Cretaceous nannoplankton biostratigraphy and oceanography of the northwestern Atlantic Ocean. Initial Reports of the Deep Sea Drilling Project $44,731-760$.

Sasvári, Á., 2008. Shortening-related deformation in the Gerecse Mts, Transdanubian Range, Hungary. Földtani Közlöny 138 (4), 383-400.

Sasvári, Á., 2009. Middle Cretaceous Contractional Deformation and Structural Burial in the Gerecse Mts (unpubl. PhD thesis, in Hungarian). Eötvös University, Department of General and Applied Geology, Budapest, 146 pp.

Schlagintweit, F., 1990. Microfaunistic investigations of Hungarian Urgonian limestones (Barremian-Albian). Acta Geologica Hungarica 33, 3-12.

Schmid, S.M., Fügenschuh, B., Kissling, E., Schuster, R., 2004. Tectonic map and overall architecture of the Alpine orogeny. Eclogae Geologicae Helvetiae 97, 93-117. 
Schmid, S.M., Bernoulli, D., Fügenschuh, B., Matenco, L., Schefer, S., Schuster, R., Tischler, M., Ustaszewski, K., 2008. The Alpine-Carpathian-Dinaric orogenic system. Correlation and evolution of tectonic units. Swiss Journal of Geosciences 101, 139-183.

Scholz, G., 1979. Das Vracon (Oberalb, Dispar-Zone) des Bakony-Gebirges (Westungarn) und eine Revision der wichtigsten Vracon-Arten der WestMediterranen Faunenprovinz. Palaeontographica A165, 1-136.

Sidó, M., 1975. The foraminifera of the Tata Formation (Upper Aptian). Földtani Közlöny 105, 155-187 (in Hungarian, with English abstract).

Somogyi, K., 1914. Neocomian deposits of the Gerecse Mountains. A Magyar Királyi Földtani Intézet Évkönyve 22, 275-347 (in Hungarian).

Stüwe, K., Schuster, R., 2010. Initiation of subduction in the Alps: Continent or Ocean? Geology 38 (2), 175-178.

Szabó, Z., 1985. Interpretation problems of folded and faulted structures using the examples of the area of Manganese ore of Úrkút, pp. 31-58. In: Kleb, B. (Ed.), Practical Structural Geology. Geological Society of Hungary, Budapest.

Szinger, B., 2008. Albian foraminifera from Vértessomló Vst-8 borehole, Vértes Mountains (Hungary). Geologica Pannonica 36, 153-185.

Szives, O., 1999. Ammonite biostratigraphy of the Tata Limestone Formation (Aptian-Lower Albian), Hungary. Acta Geologica Hungarica 42 (2), 401-411.

Szives, O., 2002. Complex Paleontological Evaluation of the Ammonite Fauna of the Basal Layers of the Tata Limestone Formation (unpubl. PhD thesis, in Hungarian). ELTE University Budapest, 150 pp.

Szives, O., Csontos, L., Bujtor, L., Főzy, I., 2007. Aptian-Campanian ammonites of Hungary. Geologica Hungarica 57, 145 pp.

Sztanó, O., 1990. Submarine fan-channel conglomerate of Lower Cretaceous, Gerecse Mts. Neues Jahrbuch für Geologie und Paläontologie, Monatshefte 1990 (7), 431-446.

Sztanó, O., Báldi-Beke, M., 1992. New data prove Late Aptian-Early Albian age of Köszörúkőbánya Conglomerate Member, Gerecse Mountains, Hungary. Annales Universitatis Scientiarium Budapestinensis, Sectio Geologica 30, 155-164.

Sztanó, O., Császár, G., Fodor, L., 2018. Cretaceous. In: Budai, T., Fodor, L., Sztanó, O., Kercsmár, Z.S., Császár, G., Csillag, G., Gál, N., Kele, S., Kiszely, M., Selmeczi, I., Babinszki, E., Thamó-Bozsó, E., Lantos, Z. (Eds.), Geology of the Gerecse Mountains. Explanatory Book to the Geological Map of the Gerecse Mountains (1:50 000)]. Mining and Geological Survey of Hungary, Budapest, 40-55, 277-289.

Tari, G., 1994. Alpine Tectonics of the Pannonian basin (unpubl. PhD thesis). Rice University, Texas, 501 pp.

Tari, G., 1995. Eo-Alpine (Cretaceous) tectonics in the Alpine/Pannonian transition zone, pp. 133-155. In: Horváth, F., Tari, G., Bokor, Cs (Eds.), Extensional Collapse of the Alpine Orogene and Hydrocarbon Prospects in the Basement and Basin
Fill of the Western Pannonian Basin. AAPG International Conference and Exhibition, Nice, France, Guidebook to Fieldtrip No. 6, Hungary.

Tari, G., Horváth, F., 2010. Eo-Alpine evolution of the Transdanubian Range in the nappe system of the Eastern Alps: revival of a 15 years tectonic model. Földtan Közlöny 140 (4), 483-510.

Tomljenović, B., Csontos, L., Márton, E., Márton, P., 2008. Tectonic evolution of the northwestern Internal Dinarides as constrained by structures and rotation of Medvednica Mountains, North Croatia. Geological Society, London, Specia Publications 298 (1), 145-167.

Van Gelder, I.E., Matenco, L., Willingshofer, E., Tomljenović, B., Andriessen, P.A.M., Ducea, M.N., Beniest, A., Gruić, A., 2016. The tectonic evolution of a critical segment of the Dinarides-Alps connection: kinematic and geochronological inferences from the Medvednica Mountains, NE Croatia. Tectonics 34, 1952-1978.

Vaskó-Dávid, K., 1991. Studies on chromite and its significance in the Lower and Middle Cretaceous of the Tatabánya Basin and Vértes Foreground. Acta Geologica Hungarica 34 (1-2), 111-126.

Wagreich, M., 1993. Subcrustal tectonic erosion in orogenic belts - a model for the Late Cretaceous subsidence of the Northern Calcareous Alps (Austria). Geology 21, 941-944.

Wagreich, M., 2001. A 400km long piggyback basin (Upper Aptian-Lower Cenomanian) in the Eastern Alps. Terra Nova 13 (6), 401-406.

Wagreich, M., 2003. A slope-apron succession filling a piggyback basin: the Tannheim and Losenstein Formations (Aptian - Cenomanian) of the eastern part of the Northern Calcareous Alps (Austria). Mitteilungen der Osterreichischen Geologischen Gesellschaft 93, 31-54.

Wright, C.W., Callomon, J.H., Howarth, M.K., 1996. Treatise on Invertebrate Paleontology, Part L, Mollusca 4, Revised, Vol. 4, Cretaceous Ammonoidea, 362 pp. Geological Society of America, Boulder, and The University of Kansas Press, Lawrence.

Young, J.R., Bown, P.R. Lees, J.A. (Eds.), 2014. Nannotax3 Website. International Nannoplankton Association. http.//ina.tmsoc.org/Nannotax3 (accessed April 21, 2014).

Zalai, Zs, Kovács, A., Molnár, G., Bereczki, L., Timár, G., Csillag, G., Fodor, L. Kercsmár, Zs, 2015. Extent freshwater limestone bank at Iván-halála Valley, Gerecse Mts., northern Hungary: a key to understand the uplift history of the region. Geophysical Research Abstracts 17. EGU 2015-9894.

\section{Appendix A. Supplementary data}

Supplementary data related to this article can be found at https://doi.org/10. 1016/j.cretres.2018.06.005 